\title{
REFLEXOS DA IMPLANTAÇÃO DO CATAMARÃ NA CIDADE DE GUAÍBA - RS
}

\author{
Maria Cristina Pedroso Nunes \\ Bacharel em Administração. Centro Universitário Metodista
}

Andrea Sander

Professor Mestre. Centro Universitário Metodista

\section{RESUMO}

Este artigo teve como objetivo principal verificar os reflexos econômicos e sociais que a implantação da linha de transporte hidroviária alternativa da embarcação Catamarã trouxe para a cidade de Guaíba. Como objetivos específicos se estabeleceu caracterizar a mobilidade urbana na cidade de Guaíba antes do funcionamento da embarcação Catamarã, através de indicadores; identificar os reflexos econômicos e sociais para o comércio da cidade de Guaíba; identificar os reflexos econômicos e sociais para os usuários do Catamarã da cidade de Guaíba; verificar a contribuição do Catamarã para a mobilidade da cidade de Guaíba, na visão de um gestor, de comerciantes da cidade de Guaíba e de usuários do Catamarã. O trabalho contou com uma revisão da literatura que constituiu o referencial teórico, abordando conceitos relacionados à sustentabilidade, à sustentabilidade urbana, responsabilidade social, e indicadores de sustentabilidade sociais e econômicos. A pesquisa realizada foi de cunho quantitativo e qualitativo, dirigida a um gestor, de dez comerciantes da cidade de Guaíba e de uma amostra de 52 usuários do Catamarã, colhidas em uma tarde, em um dia útil. Os resultados obtidos desta pesquisa mostraram que os usuários não estavam satisfeitos com o transporte público rodoviário da cidade antes do Catamarã, se dizem satisfeitos com a implantação do Catamarã, para a mobilidade da cidade, na melhora da qualidade de vida, na economia local e para a sustentabilidade ambiental da região, mas estão descontentes quanto à tarifa e os horários disponíveis desse transporte. Os comerciantes viram melhora econômica no comercio geral e em seus negócios, na mobilidade e para a população da cidade, mas acham que falta incentivos do poder público. A gestora pública 
acredita que a cidade e a população obtiveram ganhos espetaculares em todos os sentidos já mencionados pelos outros participantes e ainda para a cultura e a autoestima da cidade.

PALAVRAS-CHAVE: Sustentabilidade urbana. Indicadores de sustentabilidade sociais e econômicos. Transporte Sustentável.

\section{REFLECTIONS OF THE CATAMARAN IMPLANTATION IN THE CITY OF GUAÍBA - RS}

\section{ABSTRACT}

This work aimed to verify the economic impacts on trade and the quality of life of the inhabitants of the city of Guaíba with the implementation of transmission line waterway alternative catamaran vessel. Specific objectives are established to characterize urban mobility in the city of Guaíba before operating the catamaran vessel through indicators; identify economic consequences for trade in the city of Guaíba; identify the effects on the quality of life of the inhabitants of the city of Guaíba with the alternative waterway transport line deployment Catamaran boat, and check the Catamaran's contribution to mobility in the city of Guaíba, in the view of a manager, from city merchants Guaíba and users of Catamaran. The work included a review of the literature that was the theoretical framework, addressing concepts related to sustainability, urban sustainability, social responsibility, and social and economic sustainability indicators. The survey was quantitative and qualitative nature, aimed at a manager, ten traders in the city of Guaíba and a sample of 52 users Catamaran, harvested in one afternoon on a weekday. The results of this research showed that users were not satisfied with the public road transportation of the city before the Catamaran, say they are satisfied with the implementation of the Catamaran, to the mobility of the city, to improve the quality of life in the local economy and environmental sustainability of the region, but are unhappy about the rate and the time available this transport. Traders realized an improvement in the economy in general and trade in their business, mobility and the city's population, but consider that lack of government incentives. Public management believes that the city and the people have made great gains in every way mentioned by the other participants and for the culture and the self-esteem of the city. KEYWORDS: Urban Sustainability, social and economic sustainability indicators, Sustainable Transportation 


\section{INTRODUÇÃO}

O cenário mundial passa, por grandes transformações, com o aumento da população urbana. Em 1900, apenas um décimo da população mundial vivia em cidades, hoje esse número mudou para metade de toda população mundial, em 30 anos esta proporção poderá ser de três quartos dos habitantes do planeta (ROGERS, 2011). A perspectiva é que até 2050, a população mundial irá somar mais de nove bilhões de pessoas, sendo que essas pessoas terão um padrão de vida mais elevado que o atual, estarão nas cidades e irão acarretar um esgotamento dos recursos naturais, proporcionarão o aprofundamento da pobreza energética, o fortalecimento das ditaduras do petróleo a aceleração das mudanças climáticas, a poluição, entre outras ações, que comprometem o desenvolvimento sustentável (ROSADO, 2010).

Nesse sentido, o transporte é fator chave na determinação do futuro de uma cidade no que diz respeito à competitividade econômica, emissões de carbono e qualidade de vida. As cidades moldarão o amanhã, e o transporte está no âmago do urbanismo sustentável (ALMEIDA, 2012). De acordo com Almeida (2012), ao mesmo tempo em que há um crescimento na renda da população mundial, há um aumento da demanda por acesso ao transporte. Isso faz com que a frota mundial de veículos também aumente em ritmo alarmante principalmente em países como o Brasil, China e Índia. Ainda segundo Almeida (2012), cada vez mais o transporte é identificado como a maior preocupação para a competitividade econômica local e global. Uma pesquisa com mais de 500 stakeholders de 25 cidades no mundo apontou o transporte como principal preocupação de infraestrutura e o primeiro determinante da competitividade de uma cidade. Os entrevistados afirmaram que "melhorar o transporte público e as vias" deveria ser a maior prioridade para os líderes municipais, com o objetivo de tornar a cidade

ReMAS - Revista Metodista de Administração do Sul, v. 2, N. 2, 2017 
mais competitiva para as empresas e viável para os cidadãos (ALMEIDA, 2012, p. 190).

Neste cenário, no Brasil, no final do ano de 2008, com a melhora da condição econômica brasileira e como forma de combater a crise financeira o Governo Federal adotou uma política de subsídio do Imposto sobre Produtos Industrializados (IPI), fazendo com que 17 milhões de veículos, entre automóveis e motocicletas, entrassem em circulação nas cidades brasileiras, causando um colapso na malha viária e congestionamentos e acidentes (ROGERS, 2011). O desejo das pessoas em adquirir um veículo está intimamente ligado, às condições desfavoráveis do transporte público, já que este tipo de transporte em geral, não oferece conforto, rodando lotados, com insuficiência de horários e itinerários. Desta forma, criar sistemas de transporte público integrados, tanto fisicamente, quanto no que diz respeito às tarifas é um objetivo importante para as cidades. $\mathrm{O}$ transporte exige flexibilidade e a maior parte das pessoas já utiliza diariamente diferentes meios de transporte. Esses meios precisam ser totalmente integrados, oferecendo verdadeira multimodalidade, melhorando a experiência total do usuário. $\mathrm{O}$ deslocamento diário deve estimular caminhadas, uso de bicicleta e uso de transportes públicos. Os sistemas de transporte público integrados tornam isso possível. (ALMEIDA, 2012).

Assim, visando um transporte mais sustentável, a cidade de Guaíba, no Rio Grande do Sul, viabilizou com parcerias público-privadas um projeto hidroviário, para fazer o transporte de passageiros até à capital Porto Alegre, através de embarcações denominadas Catamarãs. A partir do exposto se define o objetivo norteador desta pesquisa como: Verificar os reflexos econômicos e sociais que a implantação da linha de transporte hidroviária alternativa da embarcação Catamarã trouxe para a cidade de Guaíba. Para atingir tal objetivo, foram 
delineados os seguintes objetivos específicos: caracterizar a mobilidade urbana na cidade de Guaíba antes do funcionamento da embarcação Catamarã; através de indicadores; identificar os reflexos econômicos e sociais que a implantação do Catamarã trouxe para o comércio da cidade de Guaíba; identificar os reflexos econômicos e sociais para os usuários do Catamarã da cidade de Guaíba; e verificar a contribuição do Catamarã para a mobilidade da cidade de Guaíba;

A pesquisa se justifica, pois cada vez mais existe o entendimento de que a eficiência do transporte público é uma das premissas fundamentais para o desenvolvimento social e econômico de uma cidade ou região. A evolução histórica das cidades tem como característica mostrar que, em uma linha histórica, elas se estabeleceram ao longo de leitos de rios para permitir a fácil obtenção de água para o uso humano, animais e à agricultura, e ainda para facilidade do transporte humano e de bens e serviços entre as demais cidades e vilas construídas ao longo do eixo do rio. Também devido à característica plana que esses terrenos apresentam, se propiciou ainda a instalação das primeiras vias para o tráfego de pessoas e mercadorias (DUARTE; LIBARDI; SÁNCHEZ, 2012).

Porém, com o aumento da população, com o advento dos meios de transporte e de fornecimento de serviços básicos modernos, houve uma expansão das cidades e estas passaram a ocupar locais de relevo mais acidentado. $\mathrm{O}$ adensamento populacional, através da verticalização, trouxe novos desafios à mobilidade, a exemplo disso, o transporte de um maior número de pessoas e bens em vias projetadas para menor capacidade de tráfego (ANTP, 2014). Por este motivo, os governantes devem estar atentos à importância de projetos que visam integrar suas cidades com suas bacias hidrográficas, e é fundamental pensar como utilizá-las da melhor forma para aumentar a qualidade de vida de seus cidadãos, seja através

ReMAS - Revista Metodista de Administração do Sul, v. 2, N. 2, 2017 
do transporte público ou da criação de locais de convívio e turismo (ANTP, 2014).

A oferta de um novo modal de transporte público, frente à saturação do modal rodoviário é uma forma do Estado cumprir seu papel de indutor do bem-estar e qualidade de vida da sua população. Dessa forma, o Plano Hidroviário Metropolitano do Rio Grande do Sul viabiliza a embarcação Catamarã, que vem como um instrumento para a implantação do modal de transporte hidroviário de passageiros, norteando os investimentos públicos, e da iniciativa privada, viabilizando a prestação de um serviço público mais rápido, e sustentável para a Região Metropolitana de Porto Alegre (RMPA), colocando a disposição da população, uma nova alternativa de transporte coletivo, a serviço da mobilidade da urbana.(PLANO HIDROVIÁRIO METROPOLITANO DO RIO GRANDE DO SUL, 2014).

A todos estes fatos somam-se as muitas vantagens do transporte hidroviário frente a outras modalidades, apontadas por Silva (2015), que embora não isento de impactos, apresenta elevada competitividade quando se trata de transportar grandes volumes de cargas à grandes distâncias; exige poucas intervenções e investimentos, já que existem dezenas de milhares de quilômetros de malha viária; tem baixo custo de implantação; resulta em menor poluição sonora e do ar; tem baixos índices de acidentes fatais; e elevado potencial turístico.

A realização desta pesquisa partiu da necessidade de identificar, se a implantação do uso de um transporte alternativo, pode modificar o desenvolvimento econômico de uma cidade, assim como pode trazer mudanças quanto à qualidade de vida e na mobilidade urbana das pessoas que estudam, moram, trabalham, têm negócios, ou simplesmente fazer turismo neste lugar além de produzir dados para a academia para auxiliar futuros acadêmicos em seus trabalhos. 


\title{
FUNDAMENTAÇÃO TEÓRICA
}

A seguir serão apresentados os principais conceitos sobre as temáticas envolvidas na pesquisa, apresentando em um encadeamento lógico: primeiramente foi apresentada a sustentabilidade urbana como foco nos transportes sustentáveis, após os indicadores de sustentabilidade sociais e econômicos, e finalmente um breve caracterização da Cidade de Guaíba, região metropolitana de Porto Alegre, RS, onde foi realizada a pesquisa.

\section{Indicadores de sustentabilidade sociais e econômicos}

Seiffert (2010) afirma que as empresas estão cuidando dos aspectos sociais e ambientais, inserindo-se no contexto da cidadania, e muitas delas têm obtido benefícios econômicos e maior durabilidade em longo prazo, ou seja, o risco do investidor é menor.

\begin{abstract}
A redução do fator risco associado ao empreendimento em virtude da menor probabilidade de ocorrência de acidentes ambientais, vem tornando muitos empreendimentos mais atrativos aos investidores. Em virtude das preocupações na forma como o desempenho econômico de um empreendimento pode ser afetado pelo seu nível de desempenho sócio-ambiental, surgiram os indicadores de sustentabilidade. Esses índices fornecem subsídios para a avaliação do nível de responsabilidade sócio ambiental dos empreendimentos, permitindo compará-los de forma objetiva e isenta. Já existem muitos indicadores que permitem a alguns investidores e comerciantes combinar os interesses comerciais com consciência ecológica.(SEIFFERT, 2010, p.259).
\end{abstract}

Segundo Guimarães (1988), as raízes modernas de desenvolvimento sustentável encontram-se na Conferência de Estocolmo, de 1972, quando pela primeira vez, foi chamada a atenção para os impactos negativos do processo de desenvolvimento no meio ambiente e no tecido social, ocasião na qual, tomadores de decisão do mundo inteiro foram alertados 
sobre a existência de outras dimensões do desenvolvimento, para além da dimensão econômica. Entretanto, a definição mais aceita de desenvolvimento sustentável é a que ficou consagrada no Relatório Brundtland, de 1987, difundida durante a realização da Rio-92, podendo ser resumida à seguinte sentença: "atender às necessidades do presente sem comprometer a capacidade das gerações futuras de satisfazer suas próprias necessidades."(GUIMARÃES, 1988, p. 9).

Esse conceito surge no momento em que se reconhece o padrão de desenvolvimento em curso, que tem tido como objetivo central o progresso econômico, apresenta situações impossíveis do ponto de vista biofísico quando projetado para o futuro. Apresenta ainda o paradoxo do incremento nos índices macroeconômicos, mas de deterioração de índices socioambientais (BOISER,1997). Tanto os limites biofísicos do Planeta, como a deterioração do tecido social, apontam a necessidade de mudanças nos processos de decisão, implementação e avaliação de políticas públicas, na busca de uma nova forma de desenvolvimento.

Nascimento (2008) aborda que o Instituto Ethos dispõe de um guia de elaboração de balanço social. Esse guia usa o modelo do IBASE para agregação de indicadores, e é uma ferramenta de gestão que propõe a padronização de relatórios para a apresentação de indicadores de responsabilidade social. A proposta é que o relatório contenha informações sobre o perfil do empreendimento, o histórico da empresa, seus princípios e valores, governança corporativa, diálogo com partes interessadas e indicadores de desempenho econômico, social e ambiental - o chamado triple bottom line (TBL ou 3BL).

Os indicadores Ethos são uma radiografia das empresas no que concerne à responsabilidade social, abordando diversos aspectos e permitindo a comparação entre elas. A metodologia usada, entretanto, deixa a desejar com relação ao conceito 
de sustentabilidade, uma vez que sua proposta trata apenas dos aspectos ligados à responsabilidade social englobando as esferas social e ambiental, sem abordar o aspecto econômico, que além de refletir a própria sobrevivência da empresa, tem impactos importantes para a sociedade, tais como receita, custos e geração de impostos. Na esfera ambiental, acaba por trabalhar apenas indicadores qualitativos, o que torna a avaliação pouco abrangente (NASCIMENTO, 2008).

Por outro lado, os indicadores da gestão socioambiental estratégica trazem uma abordagem quantitativa dos benefícios socioeconômico-ambientais. Os benefícios sociais são expressos pela abrangência obtida, como o número de pessoas beneficiadas num projeto ou o aumento de renda per capita de uma comunidade. Os benefícios ambientais são expressos em unidades, como redução no consumo de água em metros cúbicos, de energia em quilowatts hora, etc. Os benefícios econômicos são expressos em valores monetários, como redução no custo do consumo de uma determinada matéria-prima ou o aumento da produtividade, em reais. (NASCIMENTO, 2008; ALMEIDA, 2007).

Conforme Almeida (2007), as diretrizes do GRI são um conjunto de indicadores e recomendações que estão se tornando referência para a criação de um padrão global de informações sobre desempenho econômico, ambiental e social. Estas são aceitas e adotadas por um número cada vez maior de empresas, representam o primeiro e mais bem-sucedido esforço de desenvolver indicadores da evolução das empresas na adesão ao conceito e às práticas de sustentabilidade. Almeida (2007) afirma ainda que:

O GRI foi criado em 1997 como um esforço conjunto da Coalition for Environmentally Responsible Economies (Ceres) e do Programa das Nações Unidas para o Meio Ambiente (Pnuma), com o objetivo de melhorar a qualidade, o rigor e a utilidade dos relatórios de sustentabilidade. Além

REMAS - Revista Metodista de Administração do Sul, v. 2, N. 2, 2017 
de fornecer indicadores e recomendações para elaboração de relatórios para todos os setores produtivos, as diretrizes propõe um formato padrão para apresentação dos relatórios.(ALMEIDA, 2007 p 138).

Almeida (2007) aborda ainda, que as diretrizes do GRI facilitam o relacionamento das empresas com as novas exigências das Bolsas de Valores e as transformações na legislação da governança corporativa ambiental. Além disso, há que se considerar sempre a contínua e crescente pressão de investidores e de ONGs por divulgação de dados de desempenho não-financeiro no mundo empresarial (ALMEIDA, 2007).

\section{Sustentabilidade urbana e transporte sustentável}

Rogers (2011) afirma que as cidades estão produzindo uma instabilidade social desastrosa e levando a um declínio ambiental das áreas que ocupam e entorno. Apesar do aumento global da riqueza, que ultrapassa em muito o aumento da população, cresce o grau de pobreza e o número de pobres no mundo. Muitos deles estão vivendo nos ambientes mais desfavoráveis, expostos a níveis extremos de pobreza ambiental, perpetuando, portanto, o ciclo de destruição e poluição. Neste contexto, as cidades estão destinadas a abrigar parcelas cada vez maiores dessas populações. Estando as questões sociais e ambientais existentes, as sociedades e cidades, caracterizadas por desigualdades, sofrem intensa privação social e causam danos ainda maiores ao meio ambiente. A pobreza, desemprego, não atenção à saúde, ensino de má-qualidade, injustiça social em todas as suas formas, comprometem a capacidade de uma cidade ser sustentável, do ponto de vista ambiental. O pensamento de Rogers (2011) considera que:

Além de oportunidades de emprego e riqueza, as cidades garantem estrutura física para uma comunidade urbana. Nas últimas décadas e por todo o mundo, o domínio público das cidades, os espaços públicos 
entre os edifícios, tem sido negligenciado ou dilapidado. Este processo aumentou a polarização da sociedade e criou mais pobreza e alienação. São necessários novos conceitos de planejamento urbano para integrar as responsabilidades sociais. As cidades crescem e transformam-se em estruturas tão difíceis de administrar, que não nos lembramos que elas existiam em primeiro lugar, e acima de tudo, para satisfazer as necessidades humanas e sociais das comunidades (ROGERS, 2011, p.1).

A este cenário se acrescentam os problemas crônicos do trânsito, em uma realidade onde o número de veículos é maior do que a capacidade das vias disponíveis. Assim, a circulação excessiva de veículos nas áreas urbanas, seja para o transporte privado, seja para o coletivo, de pessoas ou de cargas, deve ser discutida sob vários aspectos, entre eles do seu impacto no meio-ambiente. A análise de Duarte, Libardi e Sánchez (2012) acrescenta que:

O crescimento acelerado dos centros urbanos nos últimos anos e o aumento do número de transportes individuais no total de viagens motorizadas vem desconfigurando o papel das cidades, o de proporcionar qualidade de vida de circulação, intensificando os conflitos entre diferentes modos de deslocamentos e gerando gastos econômicos vultuosos, na tentativa de viabilizar o fluxo de veículos motorizados. O grande desafio que deve ser abraçado pela mobilidade urbana é a inclusão de parcelas consideráveis da população na vida das cidades, promovendo inclusão social à medida que proporciona acesso amplo e democrático ao espaço urbano.(DUARTE; LIBARDI; SÁNCHEZ, 2012, p.11).

O autores ainda destacam que, com as questões ambientais sendo discutidas e priorizadas, o planejamento urbano passa a desenvolver não só uma política de mobilidade, mas incorpora também o conceito de sustentabilidade, incentivando o uso de transporte coletivo e dos não motorizados de maneira efetiva, socialmente inclusiva e ecologicamente sustentável. Essa mobilidade é constituída de todos os sistemas modais de transporte, bem como de suas inter-relações, como a articula-

ReMAS - Revista Metodista de Administração do Sul, v. 2, n. 2, 2017 
ção do uso do solo, do planejamento urbano e da qualidade ambiental (DUARTE; LIBARDI; SÁNCHEZ, 2012).

Uma preocupação que tem um paralelo muito próximo ao congestionamento é a questão da emissão de poluentes pelos veículos, pois se sabe que quando veículos de um modo geral e os caminhões em especial, trafegam em velocidades muito baixas, a emissão de poluentes aumenta (MACHADO FILHO, 2001).

Desde o século passado, a temperatura média do planeta subiu. A emissão de dióxido de carbono, junto com o metano, óxido nítrico e ozônio, gazes classificados como causadores do efeito estufa sobem até a baixa atmosfera, retém o calor do sol, aumentando a temperatura média do planeta, provocando mudanças no clima. (DUARTE; LIBARDI; SÁNCHEZ, 2012).

O transporte rodoviário é responsável pela emissão de $18 \%$ do $\mathrm{CO}_{2}$ na Inglaterra. Esse assunto está intimamente relacionado com a poluição do ar, porque mesmo que a emissão de $\mathrm{CO}_{2}$ fosse extinta, a temperatura da terra ainda estaria cometida de um aumento de 0,5 a 1,5으 $\mathrm{C}$ (MACHADO FILHO, 2001).

Neste sentido Machado Filho (2001) destaca que, embora o transporte rodoviário seja o maior causador da poluição do ar, a maioria dos poluentes é proveniente dos automóveis.

O efeito do ruído na saúde humana, dependendo nível de exposição, pode ser significativo, afetando a concentração e a produtividade e causando tensões prejudiciais a saúde. Efeitos extremos podem ocorrer na forma de defeitos de audição, estresse e insônia (VASCONCELLOS, 2012). Este autor ainda expõe que:

O volume de tráfego e sua composição têm um grande impacto no ruído produzido. Veículos pesados, como caminhões e ônibus, assim como as motos, são os maiores contribuintes individuais para o barulho. A forma como os veículos são dirigidos e a sua velocidade também têm influência. Nas área urbanas, os trens podem causar grande impacto 
sonoro. O nível de ruído em uma via coletora (100 veículos por hora) é 17 vezes maior que de uma via local (seis veículos por hora) e o nível de ruído de uma via arterial de grande movimento (2 mil veículos por hora) é 333 vezes maior (VASCONCELLOS, 2012, p.105).

De acordo com Vasconcelos (2012), o transporte inclui formas indiretas de poluição, por meio de resíduos deixados pela operação dos veículos, principalmente os pneus velhos, o óleo e os lubrificantes, usados e descartados e, ao final, a própria carcaça dos veículos, que é abandonada. Estes custos podem ser estimados na forma tanto do prejuízo ao solo e aos recursos naturais.

A disputa pelo espaço de circulação coloca os usuários em conflito permanente. Esse conflito é regulado pelo Código Brasileiro de Trânsito, e pela sinalização instalada nas vias. No entanto, o acesso às vias e aos meios de transporte é muito influenciado pelas diferenças sociais, políticas e econômicas entre as pessoas, como destaca Rogers (2011). Estas disputas resultam em acidentes, que constituem um grande problema, tanto nos países desenvolvidos, quanto naqueles em desenvolvimento. Uma das características dos acidentes de trânsito é que todas as vítimas são pedestres, ciclistas e motociclistas, os participantes mais vulneráveis do trânsito (ROGERS, 2011).

O fator econômico também é um problema, pois exclui quem não tem recursos para pagar as tarifas do transporte coletivo (ROGERS, 2011). Segundo Rogers (2011), para alcançar a sustentabilidade urbana, é necessário planejar a cidade, promover a acessibilidade, intensificar o uso de sistemas mais eficientes de transportes, para re-equilibrar o uso da rua e favorecer o pedestre e a comunidade.

Uma vez abordados as exigências para a sustentabilidade do transporte sustentáveis e seus principais problemas, no próximo item será apresentado um cenário atual do transporte. 


\section{Cenário atual do transporte no Brasil}

No mundo contemporâneo, a mobilidade urbana deve ser vista como um novo desafio às políticas ambientais e urbanas, onde o fator desenvolvimento social e econômico do país, devem ser levado em conta, quando as crescentes taxas de urbanização, as limitações das políticas públicas de transporte coletivo e a retomada do crescimento econômico têm implicado num aumento expressivo da motorização individual (automóveis e motocicletas), e na frota de veículos dedicados ao transporte de cargas (SILVA, 2015).

Desta forma, de acordo com dados do Ministério do Meio do Meio Ambiente (MMA), vê-se que, o padrão de mobilidade centrado no transporte motorizado individual, torna-se insustentável, tanto no que se refere à proteção ambiental quanto no atendimento das necessidades de deslocamento das pessoas dentro das cidades. O resultado disso, são os problemas de congestionamento, por meio do aumento da capacidade viária, o estímulo o uso do carro e assim gerando novos congestionamentos, alimentando ciclos viciosos que são responsáveis pela degradação da qualidade do ar, aquecimento global e comprometimento da qualidade de vida nas cidades (aumento significativo nos níveis de ruídos, perda de tempo, degradação do espaço público, atropelamentos e stress) (MMA, 2015).

Para traçar um panorama nacional dos transportes no país é necessário compreender as características do território, que é abundante em recursos hídricos, com um imenso potencial de navegação. Dos $63 \mathrm{mil} \mathrm{km}$ de extensão de rios e lagos brasileiros, 40 mil km são potencialmente navegáveis (BRASIL, 2013). No entanto, o modal hidroviário brasileiro para o transporte de passageiros ainda é pouco utilizado, sendo que as operações hidroviárias estão centradas na navegação comercial (transporte de cargas).

A expectativa do Plano Nacional de Logística e Trans- 
porte (BRASIL, 2007), entre os anos de 2020 e 2025, é de que o modal hidroviário passe a representar $29 \%$, o ferroviário $32 \%$, o rodoviário $33 \%$, o dutoviário $5 \%$ e aeroviário $1 \%$ para o transporte de cargas. Atualmente esta matriz está assim constituída: 13\% hidroviário, 30\% ferroviário, 5\% dutoviário e $52 \%$ rodoviário (BRASIL, 2007). Essa mudança na matriz do transporte de carga no país reflete a necessidade de buscar um melhor equilíbrio entre os modais, valorizando e priorizando o uso dos modais ferroviários e hidroviários devido a suas eficiências energéticas e produtividades no deslocamento de fluxos de maior densidade e distância de transporte (BRASIL, 2007).

Se considerada a matriz de transporte de passageiros o desequilíbrio é grande, como observado na Figura 1, que compara os diferentes modais para transporte de passageiros entre os anos de 2004 a 2011, que há largo predomínio do transporte rodoviário sobre os demais e que o transporte aquaviário é próximo a $0 \%$ e se observa, com $96 \%$ dos passageiros utilizando o modal rodoviário no Brasil.

Figura 1 - Matriz do transporte Passageiros no Brasil no anos de 2004 e 2011

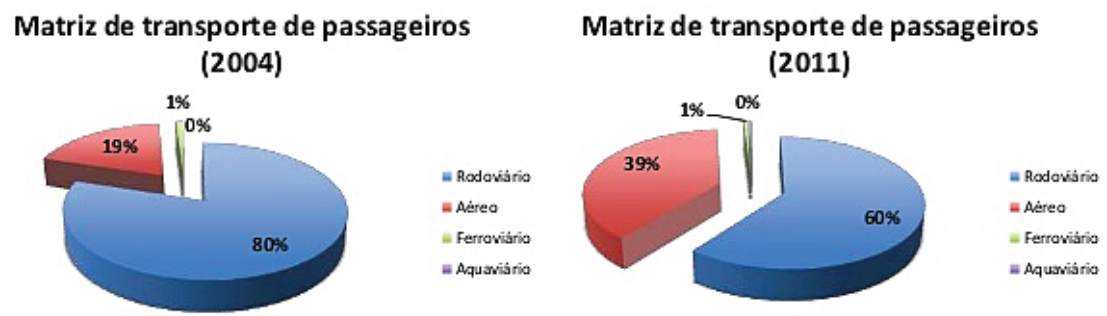

Fonte: Boletins estatísticos da CNT de 2005 e 2012

Esse descompasso se observa, possivelmente, devido aos baixos investimentos em infraestrutura nos modais ferroviário e hidroviário. O Brasil possui pouco mais de 13.000 quilôme-

ReMAS - Revista Metodista de Administração do Sul, v. 2, N. 2, 2017 
tros de hidrovias, sendo a pouco mais de 13.000 quilômetros de hidrovias, sendo a maioria concentrada na Região Norte do país, onde os rios possuem maiores calados, necessitando de menores investimentos e não são ofertadas muitas opções de modais terrestres (BRASIL, 2010). Entretanto, a partir de 2007, ocorreu um crescimento nos investimentos públicos em transporte devido à implantação do Programa de Aceleração do Crescimento (PAC) do Governo Federal, chegando a mais de 50 bilhões de reais investidos entre 2013 e 2015 (Figura 02). Entretanto, percebe-se que o transporte hidroviário é aquele que recebe menor volume de investimento.

Figura 2 - Investimentos públicos por modal de transporte entre 1995 a 2015

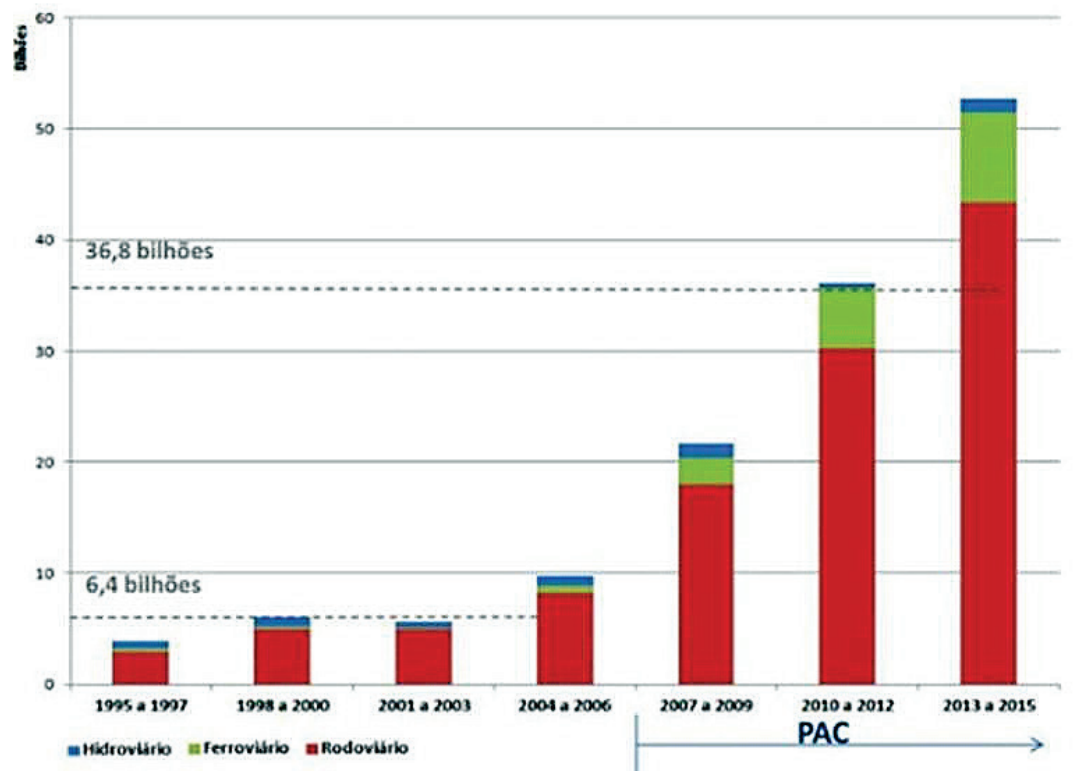

Fonte: PAC (2015) 
Para Almeida (2012), o transporte sustentável precisa ser a norma, não a exceção. O uso integrado do solo e o planejamento dos transportes, do transporte sobre trilhos, do sistema Bus Rapid Transit (BRT), de ciclovias, vias para pedestres, veículos limpos e taxas adicionais por congestionamentos devem ser práticas comuns. A regularização desses elementos básicos de mobilidade permitirão inovação e experimentação em políticas públicas e em tecnologia, promovendo as próximas gerações de soluções sustentáveis de transporte (ALMEIDA, 2012).

Affonso (2009) expõe que, em 1998, uma pesquisa realizada pelo Instituto de Pesquisa Econômica Aplicada (IPEA) em conjunto com a Associação Nacional de Transportes Públicos (ANTP) sobre congestionamentos em dez capitais, apontou um custo de R 5 bilhões, responsável por 15\% do aumento das tarifas públicas. Assim, enquanto o transporte público urbano espera por medidas de desoneração tributária, justiça social nos pagamentos das gratuidades, hoje pagas pelos usuários, e investimentos em infraestrutura, o Governo Federal e os estados de São Paulo e Minas Gerais injetaram R \$ 8,5 bilhões para manter os financiamentos para automóveis, sob pretexto de que seu bom desempenho favorece a economia. De acordo com o autor:

Em 2008 os fabricantes de automóveis foram ajudados pela isenção da Cide-combustíveis, pela redução da alíquota do IOF na compra de motocicletas, motonetas e ciclonetas por pessoas físicas, e pela redução do IPI da indústria automobilística, representando importantes renúncias fiscais. A Fenabrave festejou um crescimento de $27,8 \%$ nas vendas entre 2006 e 2007, atingindo 2,3 milhões de automóveis comercializados. Em 2008 festejou novo recorde, o maior da história, crescendo $14 \%$ sobre 2007 (de 2,3 milhões para 2,6 milhões), a despeito da crise internacional que afetou profundamente a indústria automobilística em todo o mundo (AFFONSO, 2009, p. 1).

Affonso (2009) ainda destaca que cada vez mais nota-se a necessidade de mudanças profundas nos padrões tradicionais de mobilidade, na perspectiva de que se construam cidades mais justas e sustentáveis. De acordo com o autor, o agrava-

ReMAS • Revista Metodista de Administração do Sul, v. 2, N. 2, 2017 
mento desse cenário levou à recente aprovação da Lei Federal no 12.587 de 2012, que trata da Política Nacional de Mobilidade Urbana e contém princípios, diretrizes e instrumentos fundamentais para o processo de transição, que encontram-se sintetizados no Quadro 1.

Quadro 1 - Princípios, diretrizes e instrumentos da Política Nacional de Mobilidade Urbana

- Integração (da Política Nacional de Mobilidade Urbana) com a política de desenvolvimento urbano e respectivas políticas setoriais de habitação, saneamento básico, planejamento e gestão do uso do solo no âmbito dos entes federativos;

- Prioridade dos modos de transportes não motorizados sobre os motorizados e dos serviços de transporte público coletivo sobre o transporte individual motorizado;

- Integração entre os modos e serviços de transporte urbano;

- Mitigação dos custos ambientais, sociais e econômicos dos deslocamentos de pessoas e cargas na cidade;

- Incentivo ao desenvolvimento científico-tecnológico e ao uso de energias renováveis e menos poluentes;

- Priorização de projetos de transporte público coletivo estruturadores do território e indutores do desenvolvimento urbano integrado;

- Restrição e controle de acesso e circulação, permanente ou temporário, de veículos motorizados em locais e horários predeterminados;

- Aplicação de tributos sobre modos e serviços de transporte urbano pela utilização da infraestrutura urbana, visando a desestimular o uso de determinados modos e serviços de mobilidade, vinculando-se a receita à aplicação exclusiva em infra estrutura urbana destinada ao transporte público coletivo e ao transporte não motorizado e no financiamento do subsídio público da tarifa de transporte público, na forma da lei;

- Dedicação de espaço exclusivo nas vias públicas para os serviços de transporte público coletivo e modos de transporte não motorizados;

- Monitoramento e controle das emissões dos gases de efeito local e de efeito estufa dos modos de transporte motorizado, facultando a restrição de acesso a determinadas vias em razão da criticidade dos índices de emissões de poluição.

Finte: Affonso (2009) adaptado pela autora 
Conforme Affonso (2009), estes dados são contundentes quanto às perdas sociais e econômicas que esse modelo de mobilidade promove no país, além disto o transporte público, uma solução sustentável e que cria cidades mais baratas e eficientes, são pela Constituição, de competência dos municípios, que devem investir e gerir os transportes públicos, sem entretanto receber os recursos condizentes, além de inviabilizar as propostas de se criar um fundo de investimentos permanente para essa política. Essa política rodoviarista e focada nos automóveis, promoveu o fim dos bondes, o sucateamento das ferrovias urbanas, e os ônibus perderam 20 bilhões de passageiros entre 1992 e 2005, deixando de arrecadar R \$ 29 bilhões (ANTP, 2006).

Almeida (2012) destaca que o transporte sustentável torna uma cidade acessível aos habitantes de baixa renda, tendo em vista que a segregação social, acompanhada da privação dos direitos econômicos, é uma realidade espacial desalentadora em muitas cidades brasileiras. Ao aumentar o acesso ao transporte público de preço baixo e melhorar a viabilidade do transporte não motorizado, o transporte sustentável melhora a acessibilidade para a população pobre das cidades e as torna mais inclusivas. Um exemplo do exposto por Almeida (2012) é a Tabela 1 que faz um comparativo entre o tempo e custos de viagem entre centro de Guaíba e centro de Porto Alegre, foco do estudo desta pesquisa. 
Tabela 1 - Comparativo de tempo e custos de viagem entre centro de Guaíba e o centro de Porto Alegre

\begin{tabular}{lll}
\hline & Tempo de viagem & Custo da viagem \\
\hline Automóvel & \multirow{2}{*}{30 a $40 \mathrm{~min}}$. & $\mathrm{R} \$ 7,60$ (gasolina) \\
& & $\mathrm{R} \$ 15,00$ (estacionamento) \\
Ônibus & $40 \mathrm{~min}$. a $1 \mathrm{~h} 10 \mathrm{~min}$ & $\mathrm{R} \$ 5,15$ (comum) a \\
& $\mathrm{R} \$ 7,00$ (semidireto) \\
Barca & $20 \mathrm{~min}$. & $\mathrm{R} \$ 7,35$
\end{tabular}

Fonte: site da Prefeitura Municipal de Guaíba (2015)

Os dados expostos na Tabela 1 reforçam que o entendimento de que a eficiência do transporte público é uma das premissas fundamentais para o desenvolvimento social e econômico de uma região, sendo que esta foi a principal motivação para a elaboração do Plano Hidroviário Metropolitano do Rio Grande do Sul, pois ele significa a oferta de um novo modal de transporte público, frente à saturação do modal rodoviário é uma forma do Estado cumprir seu papel de indutor do bem-estar e qualidade de vida da população (PLANO HIDROVIÁRIO METROPOLITANO DO RIO GRANDE DO SUL, 2014).

Uma vez abordado o panorama no transporte no Brasil, particularmente o que tange o transporte urbano de passageiros, o próximo item traz, um breve histórico da cidade de Guaíba, foco deste estudo.

\section{Breve histórico da Cidade de Guaíba}

De acordo com o site da Prefeitura Municipal de Guaíba (2015), o município foi criado pelo decreto $\mathrm{n}^{-}$3697, de 14 de outubro de 1926, do então Presidente do Estado, Antônio A. Borges de Medeiros. É formado pelo território dos 9ํㅜ $10^{\circ}$ e $11^{\circ}$ distritos de Porto Alegre, dos quais foram desanexados. 
A escolha da sede do município foi decidida em plebiscito à 20 de setembro de 1926, tendo vencido Pedras Brancas, a hoje cidade de Guaíba (Figura 3).

O povoado que originou a cidade, Pedras Brancas, surgiu na segunda metade do século XIX, como um centro de charqueadas, com a presença da mão-de-obra escrava, e tropeiros e tropas de gado. Ao mesmo tempo, as terras do atual município de Guaíba eram passagem para todos aqueles que, da região Sul e Oeste, desejassem chegar até Porto Alegre.

A travessia era feita pelas águas do Lago Guaíba, tanto para o escoamento da produção e transporte de passageiros, como de cargas. Inicialmente para esta travessia foram utilizadas embarcações indígenas, posteriormente canoas, barcos a vela e na segunda metade do século XIX o barco a vapor.

Figura 3 - Mapa de localização do Município de Guaíba no Rio Grande do Sul

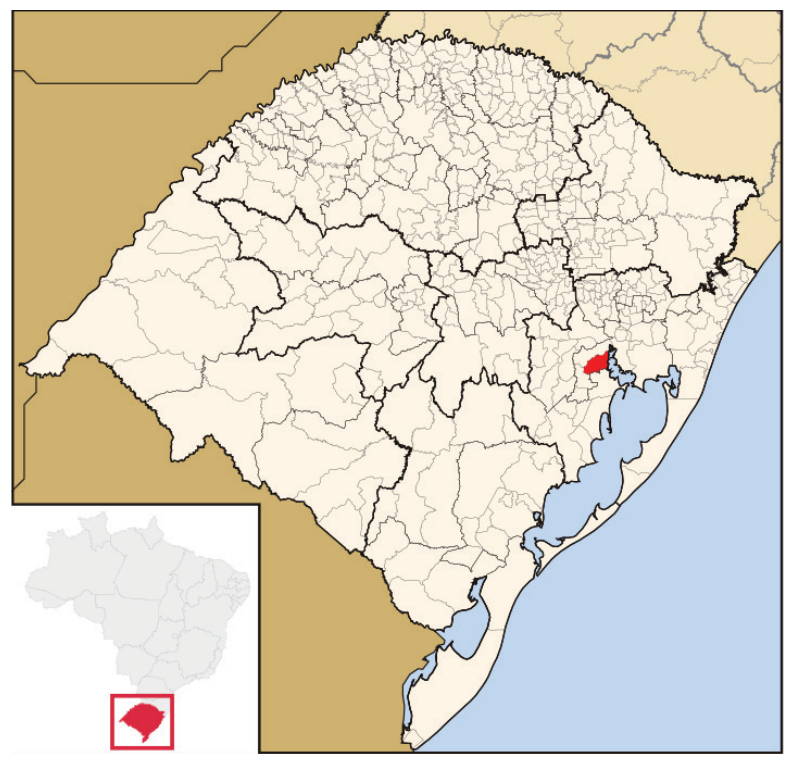

Fonte: Wikipédia. Disponível em: <https://pt.wikipedia.org/ > . Acesso em: 20 set. 2015

ReMAS • Revista Metodista de Administração do Sul, v. 2, N. 2, 2017 
A localização da cidade, à margem direita do Guaíba, um estuário de cinco rios que desemboca no Oceano Atlântico, após passar pela Lagoa dos Patos e ponto de encontro das duas rodovias federais que ligam o Brasil à Argentina e Uruguai, o município de Guaíba apresenta condições singulares de logística para empreendimentos que visam atender aos mercados do Mercosul com produtos e serviços de qualidade internacional (SITE DA PREFEITURMA MUNICIPAL DE GUAÍBA, 2015).

Inserida na região metropolitana de Porto Alegre, principal pólo econômico e cultural da região, Guaíba conta com ampla infra-estrutura de energia, serviços de comunicação, rede de ensino e serviços de saúde, complementados por adequada disponibilidade de mão-de-obra qualificada e a presença de importante indústrias exportadora certificadas pelas normas ISO 9000 e 14000.

$\mathrm{O}$ acesso em menos de 30 minutos ao aeroporto internacional completa o quadro favorável ao desenvolvimento acelerado do agribusiness, indústria, comércio e turismo, neste município com grandes áreas disponíveis para estas atividades.

De acordo com os dados do Instituto Nacional de Ciência e Tecnologia (INCT) e do Observatório das Metrópoles, com o último censo do Instituto Brasileiro de Geografia e Estatística (IBGE, 2010), revelou que a população de Guaíba contava com 95.204 habitantes (Tabela 2).

Tabela 2 - Números da Cidade de Guaíba

\begin{tabular}{ll}
\hline Números da Cidade de Guaíba & \\
\hline População estimada 2015 & 99.029 \\
População 2010 & 95.204 \\
Área de unidade territorial $\left(\mathrm{km}^{2}\right)$ & 376.947 \\
Densidade demográfica $\left(\mathrm{hab} / \mathrm{km}^{2}\right)$ & 252.57 \\
\hline
\end{tabular}

Fonte: IBGE (2010) 
Muitos destes habitantes deslocam-se diariamente à capital gaúcha para trabalhar, uma vez que Guaíba, com outras 33 cidades compõem a Região Metropolitana de Porto Alegre, e já foi caracterizada como uma cidade dormitório (INCT, 2005). A cidade até pouco tempo dispunha unicamente de transporte rodoviário, sendo que o eixos viários oferecido, as BR-116 e 290, apresentam:

forte ocupação urbana no seu entorno, sendo marcado por condições de circulação notoriamente críticas, comprometido que está pela incapacidade de acomodar os grandes fluxos de tráfego que ali se concentram nos horários de pico e até mesmo fora deles.

Disto decorre uma série que inúmeros trechos destas vias, mas particularmente da BR-116, estejam sujeitos a longos engarrafamentos, sendo a BR-116 recordista nacional em número de acidentes registrados. Estes fatos, além de contribuírem para uma baixa qualidade de vida dos moradores da RMPA, trazem prejuízos incalculáveis aos cofres públicos, transformando-se em um problema de gestão.

\section{METODOLOGIA}

Este estudo de caso buscou verificar quais os reflexos econômicos e sociais que a implantação da linha de transporte hidroviária alternativa, a embarcação Catamarã, trouxe para os usuários e o comércio da cidade de Guaíba, e foi fundamentada através de uma pesquisa com objetivos descritivos, já que buscou obter informações sobre uma determinada população.

A abordagem do problema se deu de forma mista, que segundo Creswell (2010) é o tipo de pesquisa que combina abordagens qualitativa e quantitativa, proporcionando uma melhor compreensão dos problemas da pesquisa. Atendendo as características mistas da pesquisa, a coleta de dados ocorreu sob duas formas: uma coleta quantitativa e outra quantitati- 
va. A coleta quantitativa foi realizada no transporte coletivo hidroviário, a embarcação Catamarã, no trajeto entre Porto Alegre e Guaíba, em um dia útil, no turno da tarde, entre às 13 horas e 18 horas, sendo o número da amostra calculado a partir das informações obtidas junto a empresa transporte coletivo hidroviário Catamarãs do Sul (CatSul), pertencente ao Grupo Ouro e Prata, que é a responsável pelo serviço, após vencer licitação promovida pelo Governo do Estado, em novembro de 2010. Cabe ainda caracterizar a empresa CATSUL, do Grupo Ouro e Prata, responsável pelo Catamarã. A empresa possui mais de setenta anos de tradição e experiência no transporte terrestre. Há alguns anos, vem investindo também no transporte hidroviário. Desde 2006 está presente no norte do país, onde mantém uma empresa cujos barcos navegam por águas amazônicas transportando 240 mil pessoas por ano.

A empresa informou que o número de usuários em um dia útil é de 650 passageiros, a pesquisa foi realizada em uma tarde com circulação de aproximadamente 300 passageiros na embarcação, onde a autora convidou a todos os usuários presentes no terminal a participarem na pesquisa, sendo que 52 usuários se dispuseram a responder o questionário. A pesquisa se realizou no Terminal Hidroviário de Guaíba, já que, por norma da empresa, não é possível a viagem em de pé dentro do barco, sendo liberada a execução. Nesta etapa foi utilizado um questionário que, conforme Marconi e Lakatos (2010), possibilita mensurar com maior exatidão o que se investiga, economizando tempo, atingindo maior número de pessoas e possibilitando o anonimato dos respondentes. $\mathrm{O}$ questionário foi composto de perguntas abertas e fechadas de escolha simples e de escala gradual do tipo Lickert, que conforme Vieira (2009), apresenta as respostas para cada item variando segundo um grau de intensidade. Na escala de Lickert as categorias são ordenadas, estão igualmente 
espaçadas e com mesmo número de categorias em todos os itens (VIEIRA, 2009).

Já a coleta de dados qualitativa abrangeu dez comerciantes da cidade de Guaíba, escolhidos em função da distância que ficam seus estabelecimentos do terminal da embarcação Catamarã, a cerca de duas a três quadras de distância. Os estabelecimentos se dividiram da seguinte forma: sete estabelecimentos do ramo alimentício (uma confeitaria; uma lancheria e cinco restaurantes); uma franquia do Boticário; um bazar (loja de 1 e 99); e uma loja de eletroeletrônicos.

Também foi entrevistada a Secretária de Cultura da cidade de Guaíba. Nesta etapa de coleta foi utilizada uma entrevista, baseada em roteiro estruturado com perguntas abertas e fechadas. Compete a Secretaria de Turismo, Desporto e Cultura promover e incentivar as atividades artísticas e desportivas; promover, estimular, orientar e fiscalizar as práticas esportivas do Município; elaborar o calendário anual de atividades e fatos turísticos; incentivar a indústria hoteleira do Município, levantar e manter locais verdes de valor histórico e turístico no Município de Guaíba; zelar pelo patrimônio artístico e histórico do Município; organizar e estimular a realização de exposições e certames, festejos cívicos, sócio-econômicos e folclóricos de caráter local e regional; promover realizações culturais e artísticas; estimular os esportes amadores; administrar os ginásios de esportes, campos e canchas esportivas de propriedade municipal; incentivar a Casa de Cultura, Museu Municipal e espaços culturais.

A entrevista, na visão de Severino (2011), é a técnica de coleta de informações sobre um determinado assunto, diretamente solicitadas aos sujeitos pesquisados. Trata-se, portanto, de uma interação entre pesquisador e pesquisado.

Adicionalmente, foi utilizada a observação, apoiada em roteiro pré-estabelecido em diário de campo, que, na visão 
de Marconi e Lakatos (2010, p. 190), consiste em uma técnica de coleta de dados onde, para se levantar as informações pretendidas se "utiliza os sentidos na obtenção de determinados aspectos da realidade. Não consiste apenas em ver e ouvir, mas também em examinar fatos ou fenômenos que se desejam estudar."

Como esta foi uma pesquisa de caráter misto, foi seguida a determinação Creswell (2010), que expõe que a análise dos dados esta relacionada ao tipo de estratégia de pesquisa utilizada, e ocorre tanto na "abordagem quantitativa (análise numérica descritiva e interferencial) quanto na qualitativa (descrição e análise temática de texto ou imagem), e frequentemente entre as duas abordagens." (CRESWELL, 2010 p. 257). Adotando esta metodologia, se esclarece que os dados quantitativos foram tabulados, gerando gráficos de setores, interpretados com estatística descritiva, que na concepção de Guedes et al. (2005) é aquela:

cujo objetivo básico é o de sintetizar uma série de valores de mesma natureza, permitindo dessa forma que se tenha uma visão global da variação desses valores, organiza e descreve os dados de três maneiras: por meio de tabelas, de gráficos e de medidas descritivas.(GUEDES et al., 2005, p. 1).

Já os dados qualitativos foram transcritos e organizadas, possibilitando sua comparação entre os diferentes grupos de entrevistados, comerciantes e gestor(es) e entre os dados obtidos com a pesquisa quantitativa e com a observação. Uma vez confrontados os dados o próximo passo foi a análise interpretativa dos mesmos, técnica definida por Marconi e Lakatos (2010) como aquela que busca:

fazer uma crítica, do ponto de vista da coerência interna e validade dos argumentos empregados no texto e da profundidade e originalidade dada à análise do problema, realizar uma apreciação pessoal e mesmo 
emissão de juízo sobre as ideias expostas e defendidas (MARCONI; LAKATOS, 2010, p. 32).

De forma a completar à análise foi realizada a comparação com o referencial teórico previamente abordado, como preconiza Gil (2010):

Após, ou juntamente com a análise, pode ocorrer também a interpretação dos dados, que consiste, fundamentalmente, em estabelecer a ligação entre os resultados obtidos com outros já conhecidos, quer sejam derivado de teorias, quer sejam de estudos realizados anteriormente (GIL, 2010, p.113).

Desta forma se pretendeu alcançar as respostas para os objetivos propostos no presente artigo.

\section{RESULTADOS E DISCUSSÃO DA PESQUISA}

A fim de caracterizar a mobilidade urbana na cidade de Guaíba antes do funcionamento da embarcação Catamarã, pelos usuários da embarcação, foram elaboradas nove perguntas que auxiliaram a pesquisadora nesta tarefa. As primeiras três perguntas foram abertas, sendo que a primeira questão dirigida aos usuários da linha do Catamarã abordou os meios de transporte para deslocamento até Porto Alegre, obtendo como resposta, o ônibus ou carro particular. A seguir foi questionado sobre a disponibilidade de horários do transporte coletivo rodoviário, com maioria dos usuários pesquisados classificando estes como insuficientes, e indicando que os coletivos saem de Guaíba em direção à capital a cada hora. A seguir foram questionados sobre o tempo médio deste deslocamento, os respondentes afirmaram ser em torno de uma hora.

As próximas seis questões utilizaram a escala Lickert e estão expressas em gráficos, sendo assim foi questionado aos usuários da linha do Catamarã sobre a acessibilidade antes 
da implantação do transporte hidroviário, os respondentes mostram-se $46 \%$ insatisfeitos com um total de 59\%, desses $13 \%$, estão plenamente insatisfeito com os poucos horários oferecidos, pouca disponibilidade de saída dos bairros sendo que as respostas estão expostas no Gráfico 1.

Gráfico 1 - Satisfação com o transporte coletivo em Guaíba antes da implantação do Catamarã

\section{Antes da implantação do Catamarã, a acessibilidade o transporte coletivo em Guaíba era:}
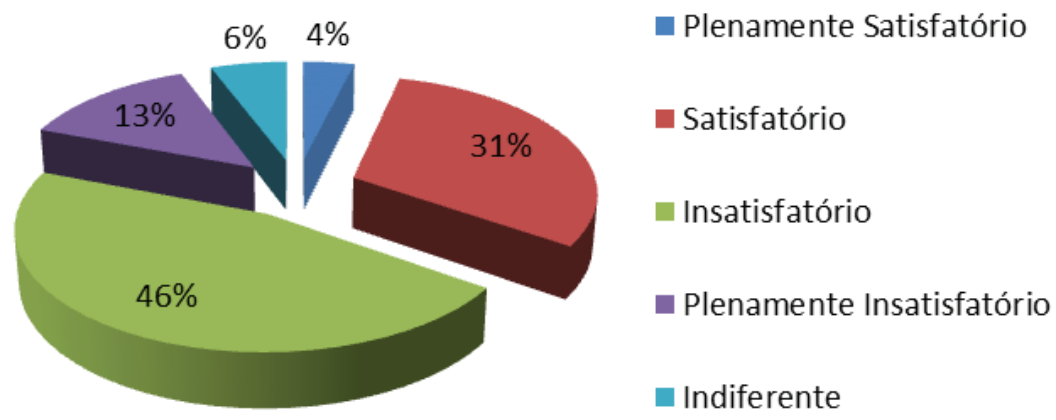

Fonte: a autora (2016)

Neste quesito, se traz à discussão Duarte, Libardi e Sánchez (2012), que afirmam que o grande desafio que deve ser abraçado pela mobilidade urbana é a inclusão de parcelas consideráveis da população na vida das cidades, promovendo inclusão social à medida que proporciona acesso amplo e democrático ao espaço urbano.

A próxima pergunta dirigida aos usuários da linha do Catamarã foi sobre o custo da tarifa antes da implantação do transporte hidroviário. Como se observa no Gráfico 2, 52\% dos 
respondentes estão insatisfeitos, e $10 \%$ plenamente insatisfeitos, com a opção de semi-direto, mais rápido, mas passagem cara, corroborando com Almeida (2012), que diz ao aumentar o acesso ao transporte público de preço baixo e melhorar a viabilidade do transporte não motorizado, o transporte sustentável melhora a acessibilidade para a população pobre das cidades e as torna mais inclusivas.

Gráfico 2 - Satisfação com a tarifa do transporte coletivo em Guaíba antes da implantação do Catamarã

\title{
Antes da implantação do Catamarã, o custo da tarifa o transporte coletivo em Guaíba era:
}

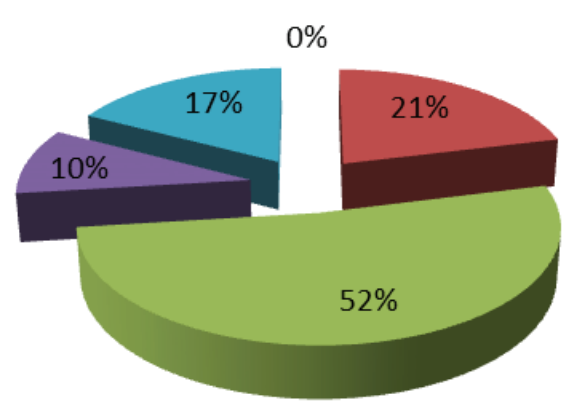

\author{
n Plenamente Satisfatório \\ - Satisfatório \\ - Insatisfatório \\ Plenamente Insatisfatório \\ - Indiferente
}

Fonte: a autora (2016)

Foi também perguntado aos usuários da linha do Catamarã sobre a segurança no transporte coletivo rodoviário de Guaíba antes da implantação do transporte hidroviário, ao que $73 \%$ dos respondentes não se sentem seguros, e desses, $15 \%$ estão plenamente insatisfeitos e $58 \%$ se sentem insatisfeitos, principalmente por causa de assaltos. Soma-se a isto, que os eixos viários oferecidos, as BR-116 e 290, particularmente da BR-116, estejam sujeitos a longos engarrafamentos, sendo a 
BR-116 recordista em número de acidentes registrados (INCT, 2005), as respostas estão expostas no Gráfico 3.

Gráfico 3 - Satisfação com a segurança no transporte coletivo em Guaíba antes da implantação do Catamarã

Antes da implantação do Catamarã, a segurança o transporte coletivo em Guaíba era:

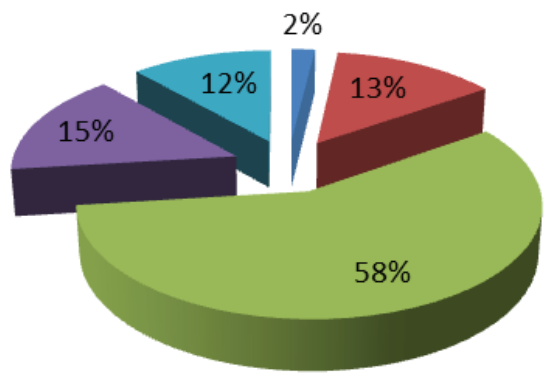

\author{
n Plenamente Satisfatório \\ Satisfatório \\ - Insatisfatório \\ n Plenamente Insatisfatório \\ - Indiferente
}

Fonte: a autora (2016)

O tempo de espera do transporte coletivo, antes da implantação do transporte hidroviário, foi tema da sétima pergunta dirigida aos usuários da linha do Catamarã, conforme expressa o Gráfico 4, sendo que $60 \%$ dos pesquisados se dizem insatisfeitos; desses, $10 \%$ estão plenamente insatisfeitos e $50 \%$ deles se dizem insatisfeitos com o tempo de espera do transporte rodoviário de Guaíba, consoante com Vasconcellos (2012) que pensa ser, um bom nível de serviço para todos os modos, seria representado por boas condições de pavimento, de sinalização e, no caso específico do transporte público, pela oferta adequada e pela disponibilidade de lugares sentados nos horários fora de pico, e espaço confortável nos períodos de pico. 


\title{
REFLEXOS DA IMPLANTAÇÃO DO CATAMAR Ã
}

NA CIDADE DE GUAÍbA - RS

Gráfico 4 - Satisfação com o tempo de espera no transporte coletivo em Guaíba antes da implantação do Catamarã

Antes da implantação do Catamarã, o tempo de espera o

transporte coletivo em Guaíba era:

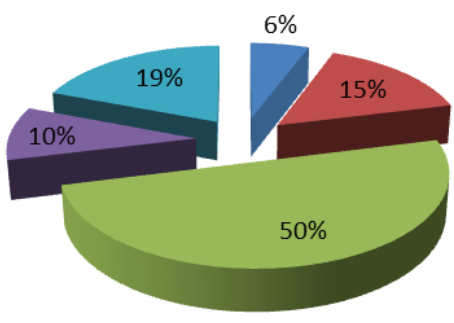

\author{
- Plenamente Satisfatório \\ - Satisfatório \\ - Insatisfatório \\ - Plenamente Insatisfatório \\ Indiferente
}

Fonte: a autora (2016)

No prosseguimento da pesquisa, foi questionado aos usuários a repeito da quantidade de linhas do transporte coletivo, oferecidos antes do Catamarã. As respostas, expostas no Gráfico 5 , mostram que $40 \%$ dos usuários estão insatisfeitos com as linhas disponibilizadas pela empresa rodoviária em Guaíba, e para $8 \%$ esse fator é plenamente insatisfatório.

Gráfico 5 - Satisfação com o número de linhas de transporte coletivo em Guaíba antes da implantação do Catamarã

Antes da implantação do Catamarã, a quantidade de linhas o transporte coletivo em Guaíba era:

Fonte: a autora (2016)

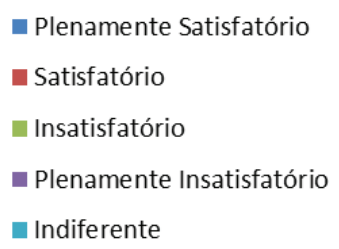


Como se pode perceber neste item e também nos anteriores é que a insatisfação dos usuários do transporte coletivo é muito grande, já que em todas as questões até aqui apresentadas a soma das opções planamente insatisfatório e insatisfatório invariavelmente somou mais de $50 \%$.. Sobre isto Gumuchdjian (2011) afirma que qualquer tentativa de reverter a situação do transporte público em cidades superlotadas vai depender da percepção que os indivíduos que pertencem à cidade têm do serviço oferecido, e que a qualidade no serviço público de transporte coletivo é absolutamente essencial para a concretização de uma cidade sustentável.

Na sequencia se investigou sobre o que pensam os usuários da linha do Catamarã a respeito da qualidade dos veículos do transporte coletivo, com $36 \%$ dos usuários se dizendo satisfeitos e $17 \%$ plenamente satisfeitos, acreditando que os veículos encontravam-se em boas condições, antes da implantação do transporte hidroviário, sendo que as respostas estão expostas no Gráfico 5.

Gráfico 6 - Satisfação com a qualidade dos veículos no transporte coletivo em Guaíba antes da implantação do Catamarã

\title{
Antes da implantação do Catamarã, a qualidade dos veículos o transporte coletivo em Guaíba era:
}

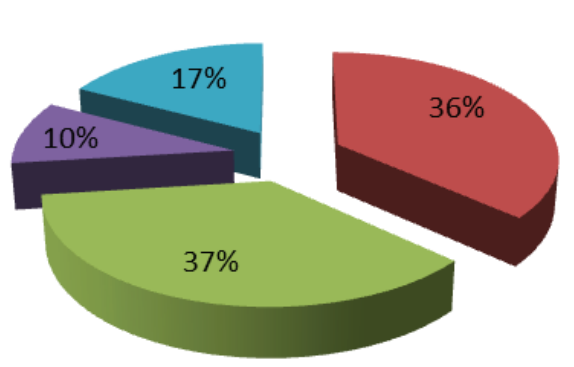

n Plenamente Satisfatório

Forlte: d autora $(\angle 010)$

\author{
- Satisfatório \\ - Insatisfatório \\ E Plenamente Insatisfatório \\ - Indiferente
}


Sobre este quesito, se destaca o que pregam Duarte, Libardi e Sánchez (2012), quando os autores afirmam que não é possível realizar programas de incentivo ao uso do transporte coletivo, se este não for capaz de garantir segurança e conforto aos seus usuários. Os autores completam, que o sistema de transporte coletivo não deve ser deficitário, que deixe de cobrir partes das cidades ou horários, pois isto desestimula o uso e deixa uma parcela da população, em geral de baixa renda, com grandes restrições à mobilidade e acessibilidade às funções urbanas. Neste contexto se observa que, se há insatisfação com os horários, tarifas, segurança e tempo de espera, pelo menos no quesito qualidade dos veículos a população se encontra atendida.

Com relação aos reflexos econômicos e sociais para o comércio da cidade de Guaíba; foram elaboradas onze perguntas, a dez comerciantes locais e nove perguntas diretas a um gestor público, que auxiliaram a pesquisadora nesta tarefa.

O primeiro tema abordado tratou sobre a percepção de mudanças decorrentes da linha Catamarã na mobilidade urbana da cidade. De acordo com a gestora entrevistada, a mobilidade urbana sofreu modificações, principalmente nos horários de pico, pois foi facilitado o acesso dos usuários ao terminal hidroviário, através de ônibus integração que passam pelos bairros transportando os passageiros, sem custo adicional, com isso diminuindo o fluxo de carros dentro da cidade e entre Guaíba e Porto Alegre, resultando em melhoria da qualidade de vida das pessoas que usam o transporte para se deslocar de uma cidade a outra à trabalho.

A percepção da gestora converge com a observação de Vasconcellos (2012), que afirma que o congestionamento está aumentando muito nas cidades brasileiras, devido, sobretudo ao crescente uso de automóveis. Isso ocorre porque cada 
veículo ocupa um grande espaço e geralmente carrega apenas uma ou duas pessoas

$\mathrm{Na}$ sequencia foi arguido a gestora a respeito dos reflexos da chegada do Catamarã sobre a receita na Prefeitura de Guaíba, ao que gestora afirmou ter havido um aumento percentual de $30 \%$, na receita da Prefeitura e também no comércio em geral, corroborando Almeida (2012), que afirma que melhorar o transporte público e as vias deveria ser a maior prioridade para os líderes municipais, com o objetivo de tornar a cidade mais competitiva para as empresas e viável para os cidadãos.

Neste ponto, a gestora salientou ter havido aumento no número de negócios no comércio geral da cidade, como abertura de novas lojas, bares e restaurantes. Conforme a entrevistada, foram abertos no total seis novos empreendimentos gastronômicos, também foi empreendido a jardineira (ônibus turístico que funciona de terça a domingo), e que estes empreendimentos resultaram na melhoria da autoestima dos habitantes da cidade, na qualificação do atendimento do comércio, melhorando a oferta de produtos. Na percepção da gestora a chegada da linha hidroviária, oportunizou novos negócios, como a entrada de lojas de rede como Americanas, Radan, Palazzo, Chocolate Caracol, Morana, entre outras. Essa modificações se acordo com Almeida (2012) se devem ao fato de que a inovação sustentável deve ser direcionada para a criação de soluções interconectadas baseadas em sistemas inovadores e com novas medidas de sucesso. Essas novas soluções não podem resultar em obsolescência ao final de um processo.

Ainda sobre o aumento na movimentação geral na cidade, o fluxo de turistas resultou em ganho, pois segundo a gestora, nos finais de semana, em função do Catamarã, passaram a circular entre duas a quatro mil pessoas pela cidade. A gestora afirma ter havido um ganho, e esse ganho se deu na qualificação da orla marítima. Também houve aumento na procura da 
cidade para realização de shows, eventos, feiras, entre outras atividades localizadas em torno do terminal Catamarã.

O próximo tema discutido, abordou a percepção de mudança na cultura das pessoas, de valorizavam mais o comércio da capital, em detrimento comércio de Guaíba. Entretanto com a chegada do Catamarã, a gestora acredita que, com as entrada de novas lojas, com o aumento dos comerciais nas diferentes mídias e de campanhas incentivando o comércio local, os habitantes ficaram mais orgulhosas da cidade, e consequentemente consomem mais em Guaíba do que antes. Duarte, Libardi e Sánchez (2012) apresentam resultados semelhantes em estudo realizado na cidade de Curitiba, onde ocorreu o fortalecimento do comércio ao longo dos eixos estruturais do transporte público somado ao estimulo do uso residencial de regiões mais distantes ao Centro, criando polos de vizinhança com moradia e comércio.

No que diz respeito a modificação na mobilidade na cidade com a chegada do Catamarã, gestora expos que, para facilitar o acesso ao centro comercial, foram empreendidas obras de infraestrutura no entorno do terminal, melhorando o acesso ao centro, como estacionamento em frente ao terminal hidroviário, calçadão, asfalto na alça de acesso ao terminal dos ônibus, realocação do Camelódromo, e reforma da Praça Gastão Leão. Isto é necessário, pois o trânsito de uma cidade não é só de passageiros, mas também de carga, de serviços, de energia e de informações. Os fluxos, além de cativos e internos às cidades, são também de passagem, regionais, de turismo e de carga, por este motivo, os governantes devem estar atentos à importância de projetos que visam integrar suas cidades com suas bacias hidrográficas (ANTP, 2014).

Para encerrar a entrevista com a gestora foi questionado sobre a melhoria na mobilidade e na qualidade de vida dos habitantes de Guaíba após a implantação do Catamarã. A gestora 
foi enfática, afirmando que "esse empreendimento trouxe para a cidade um ganho absurdo" (GESTORA, 2016), tanto para a população, como para a cidade, refletido na qualidade de vida as pessoas, no orgulho da cidade onde moram, resultando em maior empregabilidade, com aumento da utilização de mão de obra da cidade. No aspecto da mobilidade urbana, ocorreu uma otimização do tempo de viagem, diminuição o risco de acidentes, disponibilidade de transporte alternativo mais sustentável, diminuição da poluição, e o desenvolvimento da cidade através do turismo. Frente a isso, o Plano Hidroviário Metropolitano do Rio Grande do Sul (2014) viabiliza a embarcação Catamarã, que vem como um instrumento para a implantação do modal de transporte hidroviário de passageiros, norteando os investimentos públicos, e da iniciativa privada, viabilizando a prestação de um serviço público mais rápido, e sustentável para a Região Metropolitana de Porto Alegre (RMPA), colocando a disposição da população, uma nova alternativa de transporte coletivo, a serviço da mobilidade da urbana.

Buscando aprofundar a questão dos reflexos econômicos e sociais da implantação do Catamarã no comercio de Guaíba foram pesquisados dez comerciantes locais, através de um questionário com onze questões, sendo que a primeira questão dirigida aos comerciantes buscou identificar o ramo de negócio, sendo que os estabelecimentos se dividiram da seguinte forma: sete estabelecimentos do ramo alimentício (uma confeitaria; uma lancheria e cinco restaurantes); uma franquia do Boticário; um bazar (loja de 1 e 99); e uma loa de eletroeletrônicos.

A segunda pergunta dirigida aos comerciantes teve como objetivo identificar o tempo de existência do negócio, com as repostas sendo colocadas respectivamente em ordem decrescente em anos: 35, 21, 18, 16, 15, 10, 9, 8, e dois comerciantes possuem seus negócios há quatro anos, sendo que o 
Catamarã atende a cidade de Guaíba desde 2011, portanto há cinco anos atrás.

Com relação a existência de funcionários nos estabelecimentos, os dez comerciantes declararam que tem funcionários, distribuídos da seguinte forma: um comerciante possui 12 funcionários; três comerciantes possuem nove funcionários; um comerciante possui sete funcionários; outro possui cinco funcionários, dois comerciantes possuem quatro funcionários; e dois possuem dois funcionários. Ainda abordando a questão dos funcionários, foi questionado aos comerciantes sobre a necessidade de contratação de mais funcionários com o início da atividade do Catamarã, ao que 70\% dos comerciantes afirmou que sim, confirmando a expectativa do Plano Hidroviário Metropolitano do Rio Grande do Sul (2014) de mudanças socioeconômicas no entorno da embarcação com previsão do aumento de oportunidades de emprego e renda.

Com a finalidades de identificar a percepção de mudanças nos seus negócios, decorrentes da implantação do Catamarã, foi feita uma pergunta neste sentido aos comerciantes, ao que todos responderam positivamente. Seis comerciantes dizem ter notado aumento no número de turistas, e quatro perceberam um aumento na demanda de produtos por seus clientes. A percepção dos comerciantes encontra apoio na literatura, onde Duarte, Libardi e Sánchez (2012), apontam que a mobilidade urbana, baseada no transporte coletivo e associada ao resgate dos espaços públicos, como ocorreu em Guaíba com a reforma de praças, por exemplo, aliada a ampliação do comércio local, traz grande repercussão política e econômica, gerando empregos e facilitando a circulação dos pedestres em áreas comerciais.

A sexta pergunta dirigida aos comerciantes, com o objetivo de identificar um possível aumento na receita do negócio em função da implantação do Catamarã em Guaíba, resultou que oito comerciantes identificaram aumento, dentre eles, cinco

ReMAS - Revista Metodista de Administração do Sul, v. 2, N. 2, 2017 
comerciantes apontaram um aumento de receita com um percentual de $20 \%$; quatro comerciantes, um percentual de $10 \%$; e um comerciante constatou um aumento de $25 \%$ na sua receita. Estes dados vêm reforçar o pensamento de Almeida (2012), que acredita que as cidades projetadas para dirigir a parcela maior do crescimento são aquelas com maior potencial para a implementação de sistemas de transporte sustentável. Sendo assim, as decisões sobre transporte tomadas hoje, determinarão o sucesso ou fracasso de uma cidade no futuro.

A seguir se buscou identificar se o aumento de receita trouxe algum benefício aos moradores, como um maior número de promoções ou até mesmo a redução de preços, ao que oito dos dez comerciantes afirmaram não ter praticado nenhuma destas duas ações, promoção ou redução de preço, número idêntico de comerciantes que afirmou ter observado um aumento de receita com a chegada do Catamarã em Guaíba.

Em função da resposta da gestora, que relatou um aumento de $30 \%$ na receita da Prefeitura e a abertura de pelo menos cinco lojas de grandes redes, buscou-se verificar junto aos comerciantes se têm a mesma percepção, se observaram mudanças significativas no número de novos negócios em função da implantação do Catamarã. A esta pergunta, oito comerciantes reponderam afirmativamente, sinalizando que perceberam esse aumento, seguindo o pensamento de Vasconcellos (2012) que diz que a interação entre as diferentes forças e interesses dos indivíduos e das organizações privadas, públicas forma uma complexa rede, na qual estão em foco não só o indivíduo, mas todo o sistema político e econômico, o estado, o capital, a indústria e o comércio, os sistemas de transporte e trânsito, os processos migratórios e o valor da terra.

Da mesma forma, a partir da percepção da gestora pública, que sinalizou uma valorização do comercio local, em detrimento do comercio da capital após a implementação do 
Catamarã, por parte dos moradores, se questionou aos comerciantes se os mesmos observaram alguma modificação de seus clientes neste sentido, sendo que a resposta de oito foi positiva. estes comerciantes acreditam que a chegada do Catamarã proporcionou uma valorização do comercio local, assim como Werbach (2010), que advoga que se a sustentabilidade for planejada e implantada satisfatoriamente, consequentemente trará uma economia de recursos, com alcance de uma nova base de consumidores, com o dom de ganhar, manter e aprimorar empregados, clientes e sua comunidade, com reflexos sociais e econômicos, ambientais e culturais.

A décima pergunta dirigida aos comerciantes teve como objetivo identificar os mesmos identificaram mudanças na mobilidade da cidade, facilitando acesso ao centro comercial em função da implantação do Catamarã. Novamente oito dos dez pesquisados viram mudanças na mobilidade da cidade, citando as obras de infraestrutura no entorno do terminal Catamarã, melhorias no acesso ao centro comercial, como estacionamento em frente ao terminal hidroviário, calçadão, asfalto na alça de acesso a terminal dos ônibus, corroborando o que ressalta Martins (2011), que a participação da empresa na construção do bem comum de seu entorno, isto é, no modo como aprimora as funções dos que dela dependem, constitui o núcleo genuíno da construção da sua responsabilidade social.

O questionário dirigido aos comerciantes se encerra com uma pergunta que objetivou de identificar a percepção destes sobre os benefícios na mobilidade e melhoria na qualidade de vida da cidade após a implantação do Catamarã, ao que nove dos dez comerciantes acreditam ter havido melhorias, pois as cidades só podem refletir valores, compromissos e resoluções da sociedade que abrigam. Segundo Rogers (2001) e o sucesso de uma cidade, depende de seus habitantes e do poder público, 
da prioridade que ambos dão a criação e manutenção de um ambiente urbano e humano.

Para a consecução do terceiro e quarto objetivos, que buscaram respectivamente identificar reflexos econômicos e sociais para os usuários do Catamarã, e a contribuição da implantação do mesmo para a mobilidade da cidade de Guaíba, foram elaboradas onze perguntas que auxiliaram a pesquisadora nesta tarefa.

Inicialmente se procurou identificar a frequência com que estes passageiros usam o transporte hidroviários, ao que se obtiveram as seguintes repostas, expressas no Gráfico 7: 33\% dos pesquisados utiliza o Catamarã diariamente; 31\% quase sempre; e $36 \%$ dos passageiros utiliza eventualmente o serviço.

Gráfico 7 - Frequência com que utiliza o Catamarã

\section{Utiliza o Catamarã regularmente? Com que frequência?}

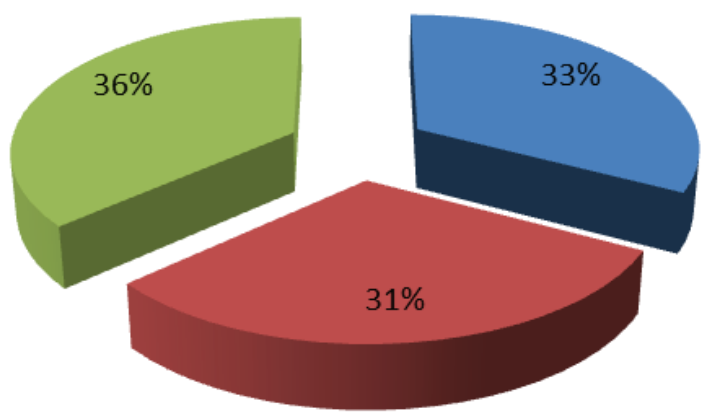

Diariamente

Quase Sempre

Fonte: a autora (2016)

A partir da percepção dos outros pesquisados, respectivamente a gestora pública e os dez comerciantes, que foram praticamente unânimes, ao perceberem modificações na mobilidade urbana de Guaíba, a exceção de um comerciante, 
dirigiu-se aos usuários do Catamarã uma questão de igual teor. Como resultado, 69\% dos pesquisados acredita que o Catamarã supre as necessidades de transporte das pessoas que se deslocam diariamente para o trabalho, fazendo com que menos veículos circulem diariamente, sendo que as respostas estão expostas no Gráfico 8.

Gráfico 8 - O Catamarã atende as necessidades de transporte de Guaíba

\section{Você acredita que o serviço coletivo Catamarâ esta suprindo as necessidades de transporte das pessoas que se deslocam diariamente para o trabalho fazendo com que menos veículos circulem diariamente?}

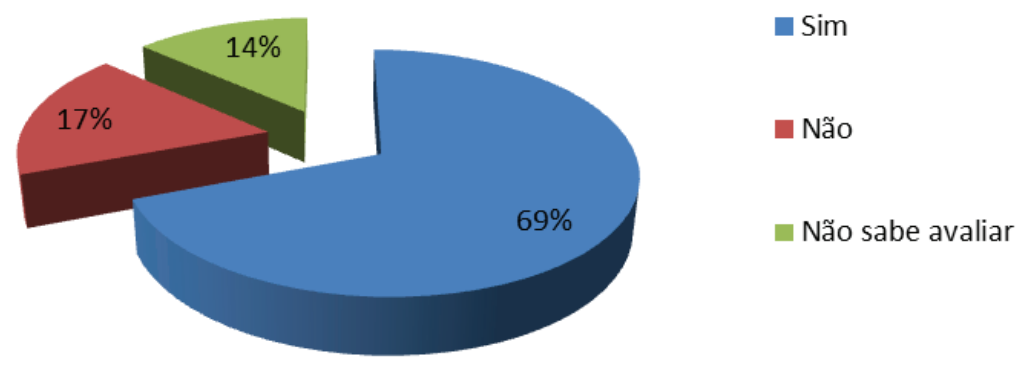

Fonte: a autora (2016)

Buscou-se a percepção dos usuários com relação a melhoria na qualidade de vida das pessoas que se deslocam do trabalho para a residência em consequência da diminuição de tempo entre estes deslocamentos, visando uma maior eficiência nos deslocamentos diários, com a ampliação da oferta e a diversificação de modais. Neste quesito, de acordo com o Plano Hidroviário Metropolitano (2014), promover o uso de outras modalidades de transporte que aproveitem o potencial natural das cidades, de forma eficaz e segura, como o transporte hidroviário, pode proporcionar a diminuição da sobre- 
carga no sistema rodoviário, público e privado, melhorando a qualidade na mobilidade urbana e a qualidade de vida dos cidadão. Neste sentido as respostas dos usuários corroborou este estudo, já que $85 \%$ dos usuários acredita que ocorreu a melhoria, e apenas $2 \%$ acredita que não houve melhoria, sendo que as respostas estão expostas no Gráfico 9.

Gráfico 9 - O Catamarã resulta em melhoria da qualidade de vida

\section{Você acredita que a diminuição do tempo dispendido, utilizando Catamarã entre deslocamentos do trabalho para residência resultou em maior qualidade de vida, para voce e para as pessoas em geral?}

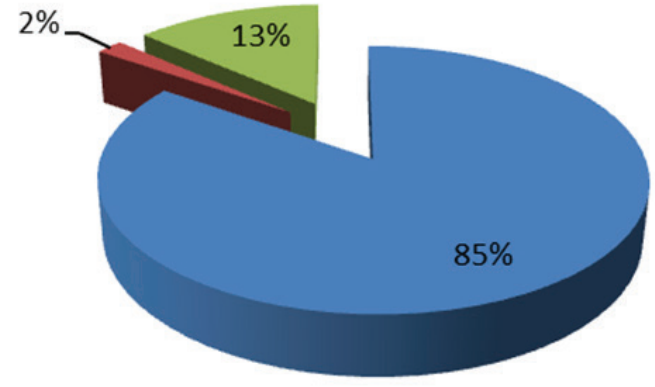

- Sim

- Não

- Não sabe avaliar

Fonte: a autora (2016)

Com relação ao valor da tarifa do Catamarã, quando se leva em conta o custo-benefício deste transporte, os usuários encontram-se $58 \%$ insatisfeitos e $9 \%$ plenamente insatisfeitos, sendo que as respostas estão expostas no Gráfico 10.

Os usuários também foram questionados quanto ao grau de satisfação em relação às rotas e horários deste transporte (Gráfico 11), resultando em $40 \%$ dos usuários insatisfeitos e $12 \%$ plenamente insatisfeitos, de acordo com o Gráfico 10. Sobre o tema, Vasconcellos (2012) afirma que a redução do 
intervalo de tempo entre dois veículos sucessivos melhora o serviço, mas diminui a rentabilidade. Ao contrário, o aumento do intervalo entre veículos aumenta a rentabilidade, mas pode causar grande queda no nível de serviço.

Gráfico 10 - Grau de satisfação com o preço da tarifa do Catamarã

\title{
O que você acha do valor da tarifa do transporte Catamarã,
} quando se pensa em custo-benefício?

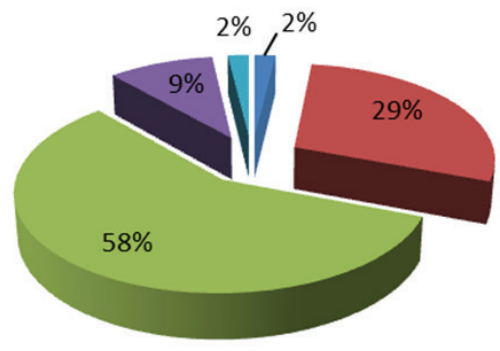

\author{
- Plenamente Satisfatório \\ - Satisfatório \\ Insatisfatório \\ - Plenamente Insatisfatório \\ Indiferente
}

Fonte: a autora (2016)

Gráfico 11 - Grau de satisfação com o as rotas e horários do Catamarã

Com relação ao grau de satisfação em relação às rotas e horários disponíveis das viagens, como você avalia o serviço?
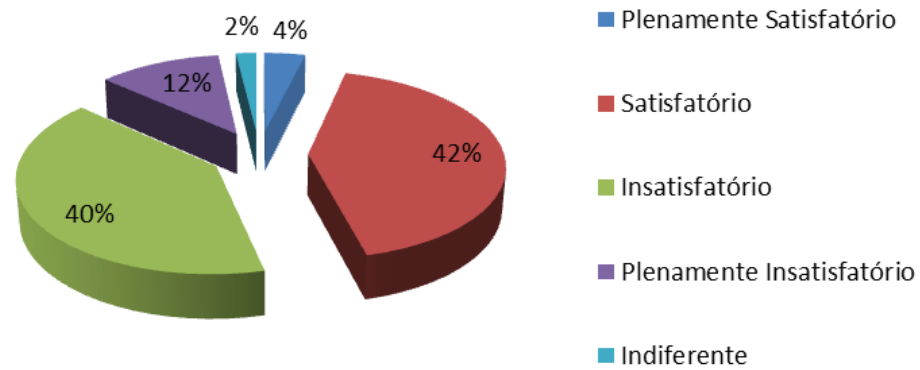

Indiferente

Fonte: a autora (2016) 
O próximo ponto verificado foi a satisfação dos usuários com a relação a acessibilidade do transporte hidroviário, ao que $65 \%$ dos usuários declararam-se satisfeitos e $23 \%$, plenamente satisfeitos (Gráfico 12). Questionados informalmente sobre o motivo da satisfação, a maioria apontou a existência de um sistema de tarifa integrada em alguns bairros. Vasconcellos (2012) já discutiu este tema, afirmando que nas cidades, cada vez maiores, as longas distâncias e a integração entre modos são cada vez mais frequentes e necessárias. Assim, implementar tarifas válidas para todo o sistema facilita a integração e aumenta a velocidade e o conforto dos deslocamentos sendo que as respostas estão expostas no Gráfico 12.

Gráfico 12 - Grau de satisfação com a acessibilidade do Catamarã

\section{Como você se sente em relação a acessibilidade do Catamarã?}

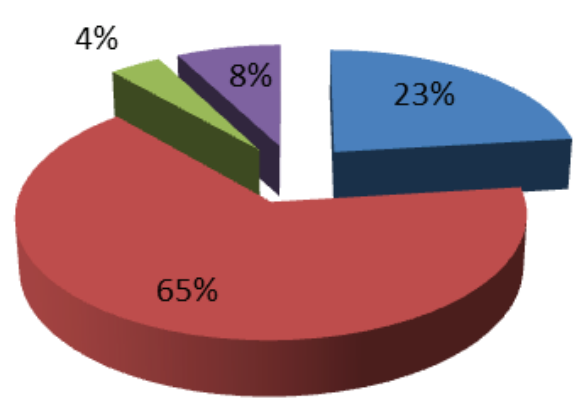

Fonte: a autora (2016)
- Plenamente Satisfatório

Satisfatório

- Insatisfatório

Plenamente Insatisfatório

Indiferente

Da mesma forma que na primeira etapa da pesquisa, nesta foi perguntado aos usuários do Catamarã sua satisfação com relação à segurança do transporte, onde $65 \%$ dos usuários encontram-se satisfeitos e $23 \%$ plenamente satisfeitos, pois segundo a CATSUL, o Catamarã é um barco seguro, com duas 
canoas, o que gera maior estabilidade, tornando a viagem mais agradável, sendo que as respostas estão expostas no Gráfico 13.

Gráfico 13 - Grau de satisfação com a segurança do Catamarã

Como você se sente em relação a segurança do Catamarã?

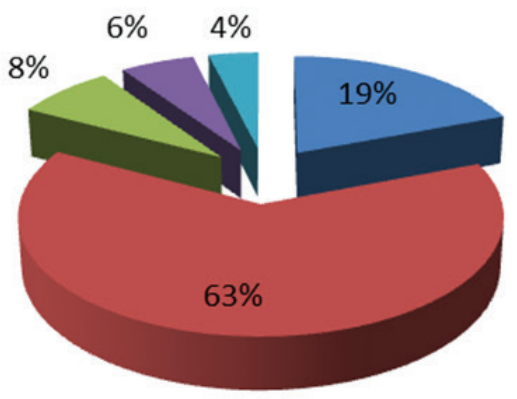

n Plenamente Satisfatório

- Satisfatório

m Insatisfatório

- Plenamente Insatisfatório

Indiferente

Fonte: a autora (2016)

A seguir foi verificada a satisfação dos usuários sobre a qualidade dos veículos da embarcação, onde 65\% dos usuários encontram-se satisfeitos e $23 \%$ plenamente satisfeitos. A CATSUL oferece aos usuários, um barco moderno, seguro com sistema de navegação por Sistema de Posicionamento Global (GPS do inglês Global Positioning Systeme) e que pode alcançar a velocidade de 24 nós $(45 \mathrm{~km} / \mathrm{h})$, permitindo a travessia, entre Porto Alegre e Guaíba, em torno de 20 minutos sendo que as respostas estão expostas no Gráfico 14. 
Gráfico 14 - Grau de satisfação com a segurança do Catamarã

\section{Como você se sente em relação a qualidade dos veículos ( acomodações, conforto e limpeza) do Catamarã?}

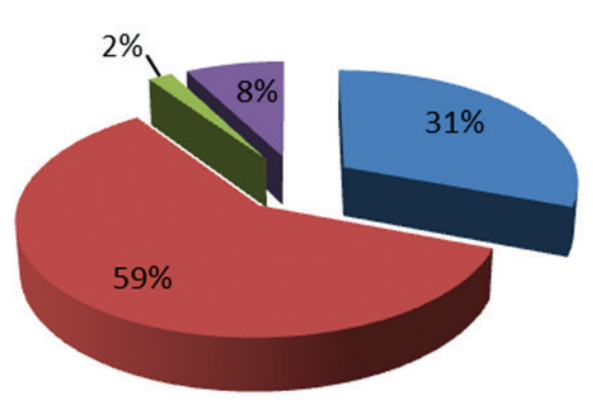

Fonte: a autora (2016)

\author{
n Plenamente Satisfatório \\ - Satisfatório \\ n Insatisfatório \\ - Plenamente Insatisfatório \\ Indiferente
}

De forma semelhante ao questionado junto ao gestor público e aos dez comerciantes, foi perguntado aos usuários sobre a sua percepção quanto a melhoria na articulação da cidade e aumento no número de comerciantes, dos respondentes, $73 \%$ acredita que Guaíba prosperou em todos os aspectos com a chegada do Catamarã (Gráfico 15). Essa visão vem complementar o conclusão da ANTP (2014), que acredita que cada vez mais existe entendimento que a eficiência do transporte público é uma das premissas fundamentais para o desenvolvimento social e econômico de uma cidade ou região. 
Gráfico 15 - Percepção de melhorias na cidade de Guaíba após o Catamarã

\section{Você sentiu melhoria na articulação da cidade, no aumento do comércio de Guaíba e acredita que a cidade ficou mais próspera após a implantação do Catamarã?}

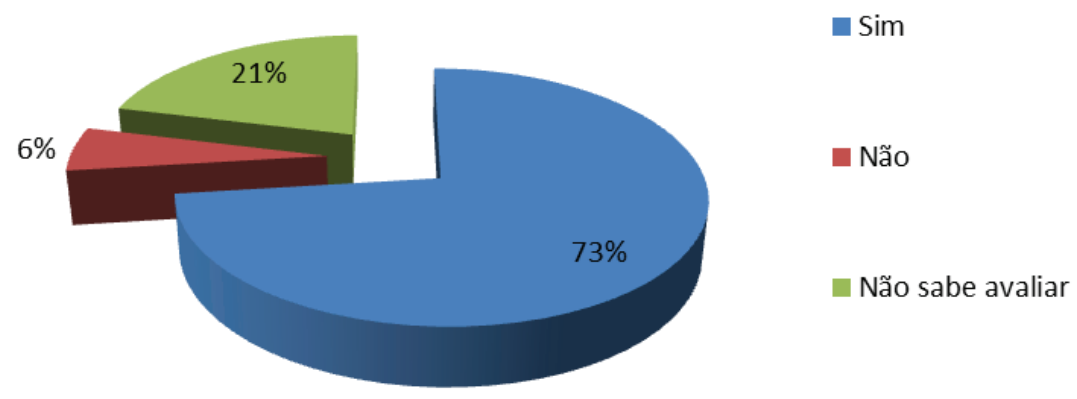

Fonte: a autora (2016)

Na sequencia foi perguntado aos usuários do Catamarã sobre a necessidade de incentivo dos governos para implantação deste modal em outras cidades metropolitanas, obtendo-se $90 \%$ dos respondentes que acham que o transporte hidroviários deve ser incentivado (Gráfico 16). Esta resposta positiva expressiva, pois se deve ressaltar que apenas $4 \%$ dos pesquisados deu uma resposta negativa, vem ao encontro de Almeida (2012), para quem o transporte sustentável precisa ser a norma não a exceção, e ainda segundo a ANTP (2014), quando o órgão afirma que os governantes devem estar atentos à importância de projetos que visam integrar as cidades com suas bacias hidrográficas.

Sobre o tema Duarte, Libardi e Sánchez (2012) manifestam que o transporte deve ser um assunto mais político do que técnico, uma vez que decisões do governo em diferentes escalas, da nacional à local, e estas decisões repercutirão na qualidade de vida da população, de acordo com o modelo adotado. 
Gráfico 16 - Expansão do transporte hidroviário para outras cidades

Você acha que este modal deve ter um incentivo maior dos governos e ser expandido para novas rotas e entre outras cidades metropolitanas?

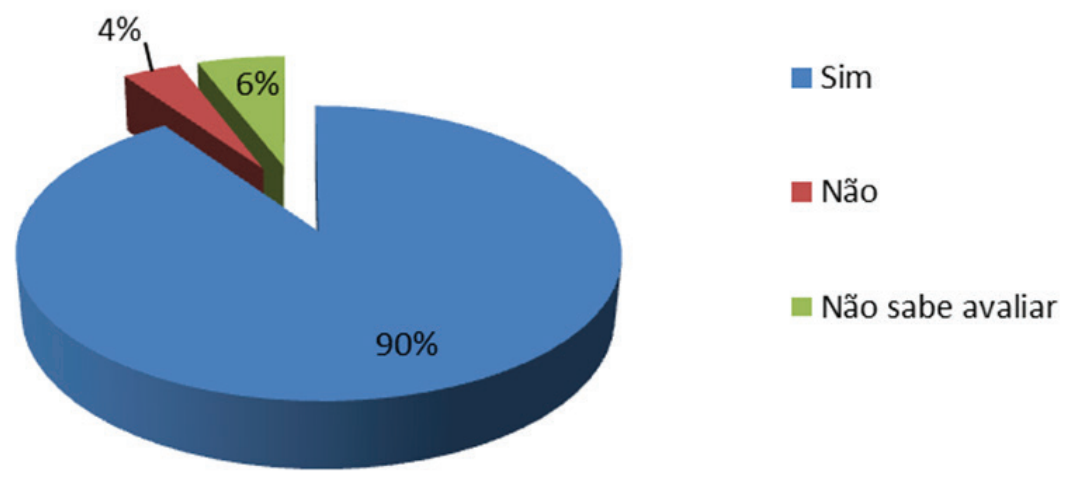

Fonte: a autora (2016)

A pesquisa junto aos usuários do Catamarã finaliza com uma questão abordando a percepção do modal como uma alternativa mais limpa na melhoria da qualidade de vida e na mobilidade urbana, ao que $90 \%$ indicaram sua satisfação nas respostas, e nenhum pesquisado declarou insatisfação, concordando com Rogers (2001) que afirma que a qualidade do ambiente urbano define a qualidade de vida para os cidadãos, sendo que as respostas estão expostas no Gráfico 17. 
Gráfico 17 - O transporte hidroviário como alternativa limpa de transporte, promotor da qualidade de vida urbana

Você acha que o transporte coletivo hidroviário, como uma alternativa mais limpa de transporte, veio melhorar a qualidade de vida da população e a mobilidade urbana?

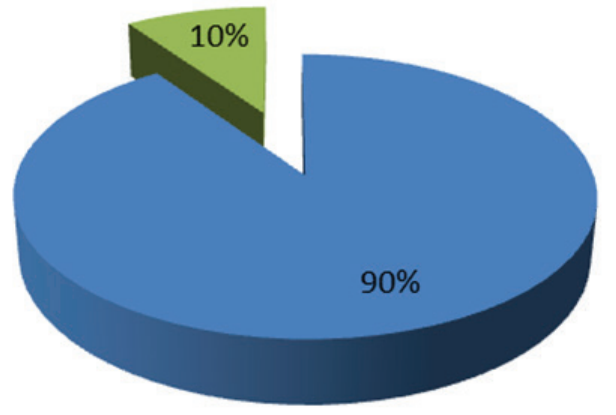

Sim

- Não

- Não sabe avaliar

Fonte: a autora (2016)

No encerramento deste capítulo de destaca a posição de Duarte, Libardi e Sánchez (2012), que afirmam que o uso do automóvel, tão cobiçado pela maioria da população, até mesmo em função da baixa qualidade do transporte público, se trata de um modal de transporte excludente socialmente, que degrada o meio ambiente e a qualidade de vida das cidades, sendo imperativo buscar alternativas. De acordo com os autores não há como banir o uso de automóveis particulares, entretanto é importante a existência de programas de incentivo aos modos coletivos ou não motorizados. Para isso, claro, é fundamental que sejam feitos programas de restrição de uso e conscientização dos motoristas de automóveis particulares de que o carro é um entre os modos de deslocamento. Mas nada disso adianta se não houver um incremento na infra-estrutura e na qualidade de serviços para os modos coletivos, neste ponto a autora desta pesquisa acredita que a cidade de Guaíba encontrou uma alternativa viável. 


\section{CONSIDERAÇÕES FINAIS}

Este artigo teve como objetivo principal verificar os reflexos econômicos e sociais que a implantação da linha de transporte hidroviária alternativa da embarcação Catamarã trouxe para a cidade de Guaíba. Como objetivos específicos se estabeleceu caracterizar a mobilidade urbana na cidade de Guaíba antes do funcionamento da embarcação Catamarã, através de indicadores; identificar os reflexos econômicos e sociais para o comércio da cidade de Guaíba; identificar os reflexos econômicos e sociais para os usuários do Catamarã da cidade de Guaíba; verificar a contribuição do Catamarã para a mobilidade da cidade de Guaíba, na visão de um gestor, de dez comerciantes da cidade de Guaíba e de uma amostra dos usuários do Catamarã, colhidas em uma tarde, em um dia útil.

Com relação a mobilidade urbana na cidade de Guaíba antes do funcionamento da embarcação Catamarã, através de indicadores, a mesma permitiu perceber a importância da eficiência do transporte público, e como esse fator, quando não é bem administrado pode interferir negativamente nos deslocamentos da população de uma cidade, pois dos seis indicadores pesquisados, que foram: a acessibilidade, o custo da tarifa, a segurança, o tempo de espera a qualidade dos veículos e a quantidade de linhas disponíveis, apenas o quesito qualidade dos veículos obteve resposta positiva e satisfação pelos usuários, sendo os outros apontados com um índice de insatisfação muito alto, para com o transporte rodoviário da cidade de Guaíba. devido a esta insatisfação por parte dos usuários o uso do automóvel, vem sendo priorizado, causando diversos problemas expostos neste artigo, além de incentivar outras formas de deslocamento como transporte coletivo clandestino, muito utilizado pelos moradores de Guaíba. A pesquisa demonstrou que há necessidade de modificações na oferta desse serviço por parte dos governantes e também 
da organização responsável pelo serviço entregue para os usuários da cidade, incentivando assim o uso do transporte coletivo rodoviário, e satisfazendo a responsabilidade social e melhorando os indicadores de sustentabilidade sociais e econômicos que cabem a eles.

Com relação aos reflexos econômicos e sociais para o comércio da cidade de Guaíba, se observou a partir da informações dos comerciantes, que a cidade obteve ganhos significativos com a chegada do transporte alternativo, foi percebido por deles um aumento nas suas receitas com a entrada de turistas na cidade, assim como um aumento no número de abertura de novos negócios, maior valorização do comércio local, a percepção de modificações na estruturação da cidade para a melhoria do acesso ao centro comercial e entorno da estação hidroviária. Entretanto os comerciantes pesquisados acreditam que a o valor da passagem do Catamarã ainda é elevado e que a Prefeitura deveria se articular melhor, para tornar a cidade mais atrativa aos turistas, contribuindo com o progresso da cidade, tirando melhor proveito deste modal sustentável de transporte. A gestora entrevistada conclui que a cidade obteve grandes ganhos, não só para o comércio, como para a população, que pode ser percebida no aumento da autoestima, na mobilidade, na qualidade de vida, e na procura da cidade para sediar eventos.

Quanto aos reflexos econômicos e sociais para os usuários do Catamarã da cidade de Guaíba, a pesquisa mostrou que a oferta desse serviço veio satisfazer pelo menos uma parte da população, pois o valor da tarifa é alto, e assim exclui uma parcela da população ao acesso ao serviço, que precisa se deslocar para a capital ou vice-versa, pois está suprindo a necessidade dos usuários quanto à acessibilidade, segurança, tempo despendido, qualidade dos veículos, mas apontou descontentamento com relação ao preço das tarifas e dos horários 
oferecidos pela empresa CATSUL. Esse descontentamento fica evidenciado com o aumento no valor das passagens e com a diminuição dos horários ofertados aos usuários. A pesquisa também mostrou que, com a implantação do Catamarã, foi percebida melhora na articulação da cidade, na abertura de novos negócios, melhoria na qualidade de vida da população, e melhoria na mobilidade da cidade. Essa melhora se reflete nas respostas como apontaram $90 \%$ dos usuários, que acreditarem que a oferta desse modal de transporte deve ser incentivado e implantado em outras regiões metropolitanas do estado, já que há uma bacia hidrográfica extensa, além desta modalidade ser uma alternativa mais limpa de transporte e com isso colaborando para a sustentabilidade como um todo.

Com relação a contribuição do Catamarã para a mobilidade da cidade de Guaíba, pelos participantes e entrevistados a pesquisa apontou que o Catamarã melhorou a vida de Guaíba, mas seriam necessárias modificações na tarifação para o serviço para ser mais inclusivo e assim, trazer mais benefícios para a população, para o comércio, para o progresso da cidade, e para a satisfazer com mais eficiência a sustentabilidade urbana e de melhorias na mobilidade dentro da cidade, com maior abrangência de integração de ônibus em todos os bairros de Guaíba e entre o trecho rodoviário referenciado.

\section{REFERÊNCIAS}

AFFONSO, Nazareno Stanislau. Automóveis e sustentabilidade. Desafios do Desenvolvimento, Rio de janeiro, v.6, n. 53, 2009. Disponível em: < $<$ http://www.ipea.gov.br/desafios/index.php?option=com_content\&view=a rticle\&id=1049: catid=28\&Itemid=23>. Acesso em: 10 nov. 2015.

ALMEIDA, Fernando. Desenvolvimento Sustentável, 2012-2050: visão, rumores e contradições. Rio de Janeiro: Elsevier, 2012.

ALMEIDA, Fernando. Os desafios da sustentabilidade: uma ruptura urgente. Rio de Janeiro: Elsevier, 2007.

BRASIL. Ministério do Meio Ambiente. Mobilidade Sustentável. Brasília, DF, [2015]. Disponível em: http:<//www.mma.gov.br/cidades-sustentaveis/ 


\section{REFLEXOS DA IMPLANTAÇÃO DO CATAMARÃ \\ NA CIDADE DE GUAÍBA - RS}

urbanismo-sustentavel/mobilidade-sustent\%C3\%A1vel.>. Acesso em: 10 nov. 2015.

CRESWELL, John W. Projeto de pesquisa: métodos qualitativo, quantitativo e misto. 3. ed. Porto Alegre: Artmed, 2010.

DUARTE, Fábio; LIBARDI; Rafaela; SÁNCHEZ, Karina. Introdução a Mobilidade Urbana. Curitiba: Juruá, 2012.

GIL, Antonio Carlos, 1946: Como elaborar projetos de pesquisa, São Paulo, Atlas, 2010.

GUIMARÃES,Roberto Pereira; FEICHAS, Quacchia; ARCANGELA,Susana. Desafios da sustentabilidade.Ambiente \& Sociedade, Campinas,v. 12, n. 2, p. 307-323, 2009. Disponível em:<http://www.redalyc.org/articulo. oa?id=31715780014>. Acesso em: 21 maio 2015.

MACHADO FILHO, Cláudio Pinheiro. Responsabilidade social e governança: o debate e as implicações; responsabilidade social, instituições, governança e reputação. São Paulo: Cengage Learning, 2011.

MARCONI, Maria de Andrade; LAKATOS, Eva Maria. Fundamentos de Metodologia Científica. São Paulo: Atlas, 2010.

MARTINS, Mônica de Araujo. Responsabilidade Socioambiental Nas Organizações: Um Enfoque Sobre A Educação Como Agente De Transformação. (LATEC/UFF) 2011.

ROGERS, Richard GUMUCHDJIAN, Philip.Cidades para um pequeno planeta. Barcelona: Editorial Gustavo Gili, 2001.

ROSADO, Berfran. Rede gaúcha de sustentabilidade ambiental. Porto Alegre; CORAG, 2010.

SEIFFERT, Maria Elizabete Bernardini; Gestão Ambiental: Instrumentos, Esferas de Ação e Educação Ambiental. São Paulo: Atlas, 2010.

SEVERINO, Antônio Joaquim. Metodologia do Trabalho Científico. São Paulo: Cortez, 2007.

SILVA, Felipe. Navegação fluvial, turismo e planejamento: as possibilidades de circulação material no território nacional o caso das hidrovias do Tietê, Paraná e Paraguai. 2015. 1 v. Tese (Doutorado em Geografia Humana) - Faculdade de Filosofia, Letras e Ciências Humanas, Universidade de São Paulo, São Paulo, 2015. Disponível em: <http://www.teses.usp.br/teses/ disponiveis/8/8136/tde-05082015-134946/>. Acesso em: 10 nov. 2015.

VASCONCELLOS, Eduardo Alcântara de. Mobilidade urbana e cidadania. Rio de Janeiro: SENAC, 2012.

VIEIRA, Sonia. Como elaborar questionários. São Paulo: Atlas, 2009. 